\title{
KRAWITAN : ANALISIS PATHET DAN JALAN SAJIAN GARAP GENDING PAKELIRAN
}

\author{
Sigit Setiawan \\ Jurusan Karawitan, \\ Institut Seni Indonesia Surakarta, \\ Jl. Ki Hadjar Dewantara No 19 Kentingan, \\ Jebres, Surakarta (57126), Jawa Tengah, \\ Indonesia \\ sigitawan03@gmail.com
}

dikirim 19-07-2021; diterima 03-08-2021; diterbitkan 17-09-2021

\begin{abstract}
Abstrak
Hal yang ingin diungkap pada penelitian ini adalah, bentuk gending, jalan sajian, dan studi pathet dalam gending Krawitan. Krawitan merupakan gending yang lebih dikenal oleh masyarakat karawitan sebagai gending pakeliran. Maka, naskah ini fokus pada jalan sajian guna keperluan pakeliran. Adapun konsep yang digunakan dalam penelitian ini adalah, teori garap Rahayu Supanggah, pendekatan kontekstual dan tekstual dalam antropologi pandangan Ahimsa Putra, yang mana pada kajian tekstual mendapat perhatian yang lebih besar. Kajian tekstual yang dihadirkan adalah kajian bentuk gending, jalan sajian, dan studi pathet. Jalan sajian dianalisis dengan menggunakan tiga contoh kasus yakni, versi Media Ajar, versi RRI dan versi Nartosabda. Sedangkan studi pathet menggunakan pendekatann pathet melalui biang pathet karya Sri Hastanto. Dari hasil analisis yang dilakukan, investigasi bentuk gending berhasil memetakan posisi ketawang gending kethuk 4 kerep yang merupakan pemekaran dari ketawang gending kethuk 2 kerep dan diawali dari bentuk ketawang. Jalan sajian, termasuk di dalam dinamika irama pada garap pakeliran ada dua versi yakni versi dari ayak-ayak dan versi buka rebab. Hal tersebut berdampak pada perjalanan Gending Krawitan. Terakhir, investigasi terkait pathet, membuktikan bahwa meski Gending Krawitan ini merupakan gending dengan pathet induk nem, tetapi pada faktanya gending ini terdiri dari frasa-frasa melodi yang tidak hanya pathet nem.
\end{abstract}

Kata Kunci:Krawitan, Pathet, Garap, Karawitan

This work is licensed under a Creative Commons Attribution-ShareAlike 4.0

\begin{abstract}
Matters to be revealed in this research are the form of gending, the method of performance, and pathet studies in gending Krawitan. Krawitan is a gending that is better known by the karawitan community as pakeliran gending. So, this paper focuses on the method of its presentation for the purposes of performance. The concepts used in this research is Rahayu Supanggah's theory of works, the contextual and textual approaches in the anthropology of Ahimsa Putra's view, in which textual studies receive greater attention. The textual studies presented is the study of the form of gending, the method of performing, and the study of pathet itself. The presentation path was analyzed using three case examples, they are; the Media
\end{abstract}


Teaching version, the RRI version and the Nartosabda version. While the pathet study uses a pathet approach through the pathet of Sri Hastanto. From the results of the analysis carried out, the investigation of the gending form succeeded in mapping the position of the kethuk kethuk 4 kerep kerep which is an expansion of the 2 kerep gending kethuk kerep and begins with the kethuk kerep form. There are two versions of the way of performing included in the rhythmic dynamics impact on pakeliran, they are; the version of ayak-ayak and the version of buka rebab. This has an impact on the journey of Gending Krawitan. Finally, investigations related to pathet proves that al though this Gending Krawitan is such a gending with the main pathet nem, but in fact this gending consists of melodic phrases that are not only in the form of pathet nem.

Keywords: keywords_1, keywords_2, keywords_3, keywords_4, keywords_5 (The scope of the study and the terms of the research that indexed in English consist of $3-5$ words)

\section{Pendahuluan}

Gending merupakan sesuatu yang sangat esensial dalam penyajian karawitan. Esensial karena gending adalah presentasi dari karawitan itu sendiri. Terdapat banyak pengertian terkait dengan gending yang lahir dari para praktisi maupun peneliti karawitan. Martopangrawit memberi pengertian gending adalah susunan nada yang telah memiliki bentuk di mana bentuknya dapat diidentifikasi berdasarkan ricikan (instrumen), struktural dan struktur lagu (Waridi 2001) dan (Martopangrawit 1975). Rahayu Supanggah yang pengrawit (pemain gamelan Jawa) handal, komposer gamelan, dan peneliti gamelan, memberikan pengertian gending justru lebih sekedar urusan lagu dan bentuk. Gending baru eksis secara nyata ketika ia sudah disuarakan oleh para pengrawit melalui jalan sajian karawitannya. Gending merupakan tapresty atau "anyaman" dari keseluruhan suara bersama ricikan (ansemble) dan/atau vokal hasil dari sajian sekelompok pengrawit dalam menafsirkan komposisi karawitan (yang dapat berupa balungan - yang secara harfiah dimaknai sebagai tulang atau kerangka dan dalam konteks gending sering dimaknai sebagai kerangka gending - essensi /imaginer, inner melody, unplayed melody) menurut seniman dan waktu serta konteks penyajiannya (Supanggah 2007). Gending adalah juga wujud komposisi yang paling dikenal di masyarakat (Supanggah 2007). Konsep "bentuk" juga menjadi titik pijak pengertian gending oleh Sri Hastanto, yang juga mengklasifikasi gending berdasarkan instrumen yang memulai untuk buka atau mengawali jalan sajian gending (Hastanto 2009). Sigit Setiawan, pada penelitiannya, dengan meramu berbagai pengertian tentang gending di atas memberikan satu pengertian gending yaitu; komposisi musikal yang dilahirkan dari permainan atau anyaman dari masing-masing ricikan dalam gamelan beserta susunan nada-nada yang diwadahi dalam berbagai bentuk dan lagu yang menghasilkan citarasa dan karakter tertentu (Setiawan 2015).

Eksistensi gending karawitan, terutama gaya Surakarta, telah lama hadir. Setidaknya data ini terdapat dalam beberapa studi terkait dengan nama-nama gending yang ditengarai sebagai sebuah repertoar gamelan. Salah satunya telah dilakukan oleh Rustopo, dengan melakukan pengamatan pada Serat Centhini yang ditulis sekitar tahun 1778 - 1820. Menurut Rustopo, ada sekitar 157 gending yang secara terang menyebutkan nama-nama gending (Rustopo 2014, 19). Lebih lanjut, dalam serat Sri Karongron, yasan dalem Ingkang Sinuwun Pakubuwana X, juga menunjukan eksistensi gending. Karya Pradjapangrawit yakni Wedhapradangga, menunjukan eksistensi gending yang paling tidak sudah ada sejak tahun 1778 hingga hari ini (Rustopo 2014). Tentu pernyataan tersebut tidak menutup kemungkinan bahwa gending justru telah hadir dan eksis dari masa-sama sebelumnya. Rustopo dengan mengamati notasi yang dituliskan empu karawitan Gaya Surakarta, Mloyowidodo, tahun 1976, 1977, dan 1978 (Mloyowidodo 1977), setidaknya terdapat 690 
gending (Rustopo 2014). Jumlah tersebut tentu belum ditambahkan dengan gending-gending yang diciptakan oleh generasi generasi pasca Mloyowidodo, penulis kira jumlahnya saat ini dapat mencapai angka ribuan.

Dari sekian banyaknya gending dalam karawitan Jawa gaya Surakarta, terdapat beberapa klasifikasi. Misalkan klasifikasi gending berdasarkan bentuknya. Klasifikasi gending sesuai dengan instrumen pokok dalam penyajiannya misalkan gending rebab dan gending bonang. Klasifikasi gending sesuai dengan instrumen yang memulai sajian, klasifikasi gending yang dikompos berdasarkan tembang seperti gending sekar atau tembang, kemudian ada gending-gending dolanan yang secara suasana penyajiannya cenderung mengedepankan estetika yang santai dan biasanya banyak repertoar yang peruntukan anak-anak kecil. Lebih jauh, bila menyinggung gending dari segi penciptaannya, terdapat pula gending-gending yang tercipta dari tembang macapat seperti yang dilakukan oleh - salah satunya - Nartosabda (Suparto 2021). Hubungannya dengan obyek kajian pada penelitian ini, Gending Krawitan merupakan salah satu gending yang diajukan oleh Warsadiningrat sebagai penguat teorinya terkait dengan penciptaan gending. Warsadiningrat berpendapat bahwa gending berasal dari sendhon atau pathetan. Salah satu yang ditengarai berasal dari pathetan slendro nem adalah Gending Krawitan ini. Sayangnya, Warsadiningrat tidak menganalisa lebih jauh hubungan ini ((Sumarsam 2003). Tetapi tulisan ini tidak bertujuan kearah pembuktian teori Warsadiningrat tersebut. Namun informasi ini memberikan nilai histori pada Gending Krawitan.

Klasifikasi gending berdasarkan hubungan gending dengan seni pertunjukan lain, semisal tari dan wayang kulit hingga kaprah menjadi gending pakeliran (wayang) atau gending beksan (tari). Pada konteks hubungan gending dengan seni pertunjukan lainnya inilah, eksistensi gending justru "terselamatkan". Sebagai contoh, gending Ketawang Santi Mulya pada praktiknya telah dikenal sebagai gending pahargyan, atau gending dalam upacara adat pernikahan Jawa (Hanifah, Listi, Rahayu, Irma Apriliyani, Rinata 2019). Demikian halnya dengan gending Krawitan yang menjadi obyek penelitian ini, di mana Krawitan, setidaknya lebih eksis sebagai gending pakeliran. Untuk mengenal hubungan wayang dan gending baca penelitian Junaidi (Junaidi, Sugiarto 2018). Pada diskursus konvensi karawitan, gending sering pula disajikan dalam berbagai kepentingan. "Berbagai kepentingan" tersebut berpengaruh pula terhadap estetika sajian gending. Sebagai contoh adalah kasus gending Ketawang Subakastawa di mana dia dapat hadir dalam berbagai kepentingan seperti untuk sajian klenengan, tari, dan wayang (Setiawan 2020).

Tulisan ini fokus pada satu sajian gending garap pakeliran. Lebih jauh mengenai pakeliran dapat membaca tulisan Sudarko (Sudarko 2010). Alasan mengapa fokus pada karawitan pakeliran, pertama, sejak kemunculannya, gending ini secara konvensional memang terkenal sebagai gending wayang, yakni pada adegan jejer sepisan atau adegan pertama pada pakeliran garap klasik kraton Surakarta. Data ini diperoleh dari tulisan Noyowirongko (Nayawirangka) berjudul Serat Pedalangan Lampahan Irawan Rabi, Jilid I terbitan Djawatan Kebudajaan Kementrian P.P. dan K tahun 1960. Noyowirongko dalam tulisannya memaparkan antara adegan pada pertunjukan wayang kulit dengan gendingnya. Salah satunya adalah keberadaan Gending Krawitan sebagai gending jejer kerajaan Dwarawati (Nayawirangka 1960) kerajaan tokoh Kresna dalam pewayangan Jawa. Selain itu dalam laporan mengenai data gending resital Jurusan Karawitan tahun 1970 - 1980, gending Krawitan dimasukan pula dalam gending pakeliran (Rustopo 2014). Data lain, video media ajar Jurusan Pedalangan ISI Surakarta, yang hari ini masih menyajikan garap pakeliran klasik gaya Kraton Kasunanan sebagai bahan ajar, juga menggunakan gending Krawitan sebagai gending jejer sepisan 
kerajaan Dwarawati. Kathryn Anne Emerson dalam bukunya berjudul "Pembaharuan Wayang Untuk Penonton Terkini : Gaya Pakeliran Garap Semalam Sajian Dramatik Ki Purbo Asmoro 1989 2017" menyebutkan, dengan melihat gaya klasik Pasinaon Dalang Mangku Negaran (PDMN) dan Radya Pustaka memberikan keterangan bahwa gending jejer sepisan adalah juga - salah satunya dapat menggunakan Gending Krawitan (Emerson 2017). Bahkan dalam dokumentasi garap pakeliran gaya klasik pedesaan yang dilakukan oleh Yayasan Lontar, gending Krawitan juga digunakan sebagai gending jejer sepisan dalam lakon Sesaji Raja Suya yang disajikan oleh Ki Purbo Asmoro (Asmoro 2013). Pada masanya gending Krawitan ini merupakan gending yang selalu disajikan pada adegan jejer sepisan. Berbeda dengan situasi hari-hari ini yang pertunjukan wayang telah berkembang dengan pesatnya (Soetarno 2011) gending Krawitan yang pernah eksis tersebut, saat ini seperti tertelan oleh waktu. Tulisan ini juga merupakan bentuk revitalisasi literasi terkait dengan gending.

Setelah mengungkap, posisi gending Krawitan dalam konteks pakeliran. Selanjutnya Gending Krawitan ini dibahas terkait bentuk, jalan sajian dan pathetnya. Lalu kenapa hal-hal yang disampaikan untuk dibahas tersebut menjadi penting untuk dilakukan. Terkait bentuknya, Krawitan merupakan gending ageng (besar) berbentuk ketawang gending yang nanti akan dibahas pada bagian pembahasan naskah ini. Analisis atau pengetahuan tentang bentuk hari ini menjadi penting, meski beberapa pendapat menyatakan bahwa bentuk bukanlah sesuatu yang dapat dikatakan lebih esensial daripada lagu gending. Pemahaman gending penting bagi mereka yang masih belajar karawitan. Hal tersebut untuk memudahkan mereka dalam belajar gending misalnya untuk menganalisis garap ricikan kendang. Sehingga mengetahui bentuk gending adalah sebuah cara awal mengenali gending sebelum merambah pada aspek yang lebih dalam seperti aspek musikal dan garap masing-masing ricikan dalam gamelan Jawa.

Jalan sajian menjadi penting untuk diketahui, karena hal tersebut yang akhirnya menjadi panduan bagi para pengrawit dalam menyajikan Gending Krawitan. Benar bahwa dinamika sajian gending adalah sesuatu yang sangat cair, luwes dan dapat disesuikan dengan beberapa aspek selain gending itu sendiri, seperti pertimbangan aspek waktu yang tersedia, dan pada kebutuhan apa gending disajikan. Namun demikian, terdapat gending-gending yang secara konvensi telah mapan dan dimaknai secara ketat mengenai jalan sajiannya. Bila melihat Gending Krawitan dalam konteks pakeliran maka kemapanan itu telah terbentuk tetapi tidak tunggal. Setidaknya ada beberapa jalan sajian yang sering digunakan dalam menyajikan gending ini. Jalan sajian diketengahkan selain juga untuk memberikan informasi keragaman jalan sajian, juga mengungkap kenapa hal itu dapat terjadi. Maka - sekali lagi, terutama bagi para pebelajar karawitan - hal ini menjadi penting untuk dimengerti.

Terkait dengan pathet, mungkin ada pertanyaan "pathetnya sudah jelas slendro nem, mengapa masih dibahas?". Tentu, pertanyaan tersebut bila disampaikan untuk hampir seluruh gending-gending gaya Surakarta, maka dapat dipastikan bahwa tidak ada diskursus pathet hingga hari ini. Pathet menjadi tidak lagi penting untuk diperbincangkan, terutama secara akademis. Hal tersebut bertolak belakang dengan fakta bahwa beberapa peneliti berhasil mengukuhkan dirinya sebagai akademisi bergelar sarjana, master, magister, doktoral bahkan professor "hanya" karena meneliti pathet. Penulis melihat, betapapun pathet tidak menjadi penting bagi para praktisi gamelan, setidaknya pathet hingga hari ini masih ada bagian tubuhnya yang masih menjadi misteri. Hal-hal ini disampaikan untuk memberikan gambaran bahwa berbicara pathet tidak sesederhana pertanyaan di atas. Atas alasan itu, pertanyaan yang hadir bukanlah seperti pada paragraf ini tetapi 
menggunakan analogi Sri Hastanto ketika membedah pathet, yakni “Mengapa gending X berpathet Y?". Pertanyaan tersebut digunakan untuk juga membedah Gending Krawitan. Sebenarnya pula bahwa gending, wayang dan pathet yang berkelindan pada persoalan tataran waktu pertunjukan dan filosofi (Reno, Wikandaru, Lasiyo, Sayuti 2019). Namun bukan menjadi kajian utama pada kertas ini.

Uraian-uraian di atas merupakan upaya penulis untuk menunjukan urgensi penelitian ini. Segala hal yang telah disampaikan kiranya cukup untuk memberikan alasan kenapa penelitian ini pantas untuk dilakukan. Untuk itu, beberapa hal yang dijelaskan dalam penelitian meliputi; bentuk , jalan sajiannya dalam garap pakeliran dan analisa pathet Gending Krawitan.

\section{Metode}

Untuk menganalisis dan menjelaskan hal-hal yang disampaikan di pendahuluan; bentuk gending, jalan sajian dalam konteks pakeliran, dan studi pathet Gending Krawitan, diperlukan beberapa konsep supaya penelitian ini jelas arah tujuannya. Konsep yang digunakan dalam penelitian ini, karena jelas melibatkan garap (sajian pakeliran) Gending Karawitan, maka penelitian ini menggunakan pendekatan garap. Rahayu Supanggah memberi pengertian garap adalah perilaku praktik dalam menyajikan (kesenian) karawitan melalui kemampuan tafsir (interprestasi, imaginasi, ketrampilan teknik, memilih vokabuler permainan instrumen/ vokal, dan kreativitas kesenimanannya.....(Supanggah 2006). Konsep ini digunakan sebagai dasar pemikiran bahwa jalan sajian Gending Krawitan adalah cerminan dari perilaku para pengrawit ketika menyajikan Gending Krawitan dalam kepentingan pakeliran. Hal ini menjadi penting mengingat bahwa pada sajian pakeliran, secara estetika, berbeda dengan garap yang lain termasuk garap klenengan (karawitan yang disajikan tanpa keterlibatan seni lainnya) dan juga gending beksan. Meski pada penelitian ini tidak memaknai estetika gending secara keseluruhan, tetapi dengan terpetakannya jalan sajian Gending Krawitan setidaknya satu pintu estetika itu terbuka.

Penelitian ini selain untuk mengetahui gending dalam perspektif garap jalan sajian, juga untuk mengetahui posisi gending dari sisi kegunaannya, atau gending pada konteks yang lain. Untuk itu, penelitian ini juga menggunakan pendekataan antropologi untuk mengkaji seni pertunjukan dalam sudut padang teks dan konteks. Ahimsa-Putra memberikan tawaran pendekatan terkait dengan teks dan konteks, yaitu, kajian yang memandang fenomena kesenian (musik, tari, sastra, sastra lisan dan sebagainya) sebagai suatu teks yang relatif berdiri sendiri, dan kajian yang menempatkan fenomena tersebut (fenomena seni) dalam konteks yang lebih luas luas, yaitu konteks sosial budaya masyarakat tempat fenomena seni tersebut muncul dan hidup (Ahimsa-Putra 2000). Pendekatan tersebut digunakan untuk melihat Gending Krawitan dalam sudut pandang tekstual dan kontekstual. Tekstual berarti kerja analisis bentuk, jalan sajian, dan pathet itu sendiri sedangkan kontekstual melihat Gending Krawitan sesuai dengan konteks gending itu disajikan. Perlu penulis sampaikan, bahwa kerja kontekstual tidak akan dibahas secara khusus, tetapi hanya menunjukan bahwa Gending Krawitan dalam penelitian dimaknai sebagai gending dalam konteks garap pakeliran. Kerja tekstualnya, yang juga menjadi fokus pada tulisan ini, sengaja untuk dipertajam dan dipertebal.

Tulisan ini adalah untuk mengurai Gending Krawitan dari sudut pandang pathet, maka perangkat analisis dalam penelitian ini adalah pendekatan studi pathet. Pathet menurut Sri Hastanto adalah urusan rasa seleh. Meski tidak sesederhana yang kita bayangkan ketika membahas apa itu rasa seleh, dalam penelitian ini, pathetnya Sri Hastanto membantu menunjukan rasa seleh apa saja 
yang membentuk Gending Krawitan hingga para pengrawit menggolongkannya sebagai gending berpathet nem. Seperti dalam penelitiannya, pada setiap pathet (nem dan sanga), Sri Hastanto membaginya dalam tiga kategori gending yaitu; gending yang mengandung frasa pathet murni, gending yang mengandung frasa pathet tidak biasa tetapi masih dapat dirasakan dalam pathet yang sama, dan terakhir, gending yang mengandung frasa pathet kontroversial (Hastanto 2009). Gending Krawitan dari sudut pandang pathetnya ditengarai berpathet nem, yang menurut pengertian Hastanto bahwa pathet nem ini dapat berarti memiliki frasa pathet nem dominan meski pada perjalannya juga terdiri dari pathet yang lain, manyura dan sanga. Piranti yang digunakan guna menganalisis pathet pada Gending Krawitan, tulisan ini menggunakan apa yang disebut “Biang Pathet". Lebih lanjut dijelaskan pada bagian pembahasan.

Penelitian ini tentu membutuhkan apa yang disebut dengan metodologi, istilah yang kemudian dianggap sama dengan metode. Menurut Ratna, metodologi memiliki dua pengertian, yaitu a). ilmu mengenai metode, dan b). proses yang dilakukan sejak awal hingga akhir penelitian. Metodologi adalah prosedur ilmiah, di dalamnya termasuk pembentukan konsep, proposisi, model, hipotesis, dan teori termasuk di dalamnya adalah metode itu sendiri (Nyoman Kutha 2010) Untuk itu, metodologi bukan pemakaian teori-teori (Tuchman dalam Ratna, 2010 : 41).

Guna memenuhi standar keilmiahan dan mentaati disiplin akademik, maka data-data diperoleh melalui berbagai metode, seperti metode lapangan - mendengarkan secara mendalam rekaman gending yang dianalisis - dan metode pustaka. Dua metode tersebut digunakan untuk mengamati secara langsung penyajian Gending Krawitan dalam sajian garap gending pakeliran. Metode pustaka digunakan untuk mengumpulkan data dari sumber literasi terkait dengan Gending Krawitan, terutama perihal pembahasan pathet dan jalan sajian, termasuk di dalamnya notasi dan informasi tentang sejarah Gending Krawitan. Data yang dianalisis terkait pembahasan pathet dan jalan sajian pada Gending Krawitan adalah, pertama video pembelajaran Jurusan Pedalangan ISI Surakarta (Media Ajar). Kedua, rekaman audio pakeliran Ki Anom Suroto lakon Kresna Duta, bersama Paguyuban Riris Raras Irama, koleksi Kusuma Record nomor seri KWK 001 (RRI) dan ketiga, rekaman pakeliran Ki Narto Sabdo lakon Parikesit Grogol (Nartosabda). Pemilihan data audio atas pertimbangan kemampuan garap dalam menyajikan karawitan, atau dalam pengertian, bahwa ketiga sumber terpilih, sudah teruji kapasitasnya dalam penyajian gending, serta telah menjadi kiblat garap karawitan, bahkan hingga hari ini.

Data yang ada, kemudian diperkuat dengan beberapa data dari hasil wawancara. Adapun nara sumber yang dilibatkan adalah tokoh seniman yang mempunyai kapasistas sebagai empu karawitan saat ini seperti, Sukamso, Suraji dan Suwito Radyo. Sukamso adalah empu karawitan gaya Surakarta, yang juga pengajar di Jurusan Karawitan ISI Surakarta. Sukamso adalah juga penggender handal dan penggarap gending tradisi yang mumpuni. Demikian juga dengan Suraji, empu karawitan, pengrebab hebat, dan "pustaka hidup" garap gending tradisi Surakarta serta juga sebagai dosen di Jurusan Karawitan ISI Surakarta. Pun juga Suwito Radya adalah pengrawit hebat dari Klaten yang multi talenta karena dapat menyajikan semua ricikan gamelan dengan sangat baik, pengendang elok, penggender bagus, dan tokoh paling mengerti soal garap karawitan baik gaya Surakarta dan gaya Nartosabdan di antara para pengrawit generasinya. Ketiganya merupakan praktisi karawitan yang hingga saat ini sulit terbantahkan kapasitas dan kapabilitasnya di dunia karawitan. Selain itu, karena jalan sajian ini juga terkait kerja pengendang, maka pengendang juga dijadikan sebagai narasumber pada penelitian ini, seperti Purnomo, dan Sri Eko Widodo. Keterlibatan para nara sumber sekaligus bentuk konfirmasi dan triangulasi data supaya data yang 
diperoleh tidak hanya berdasarkan satu sumber. Berikut penggambaran metode penyusunan naskah penelitian ini apabila mewujud pada satu bagan.

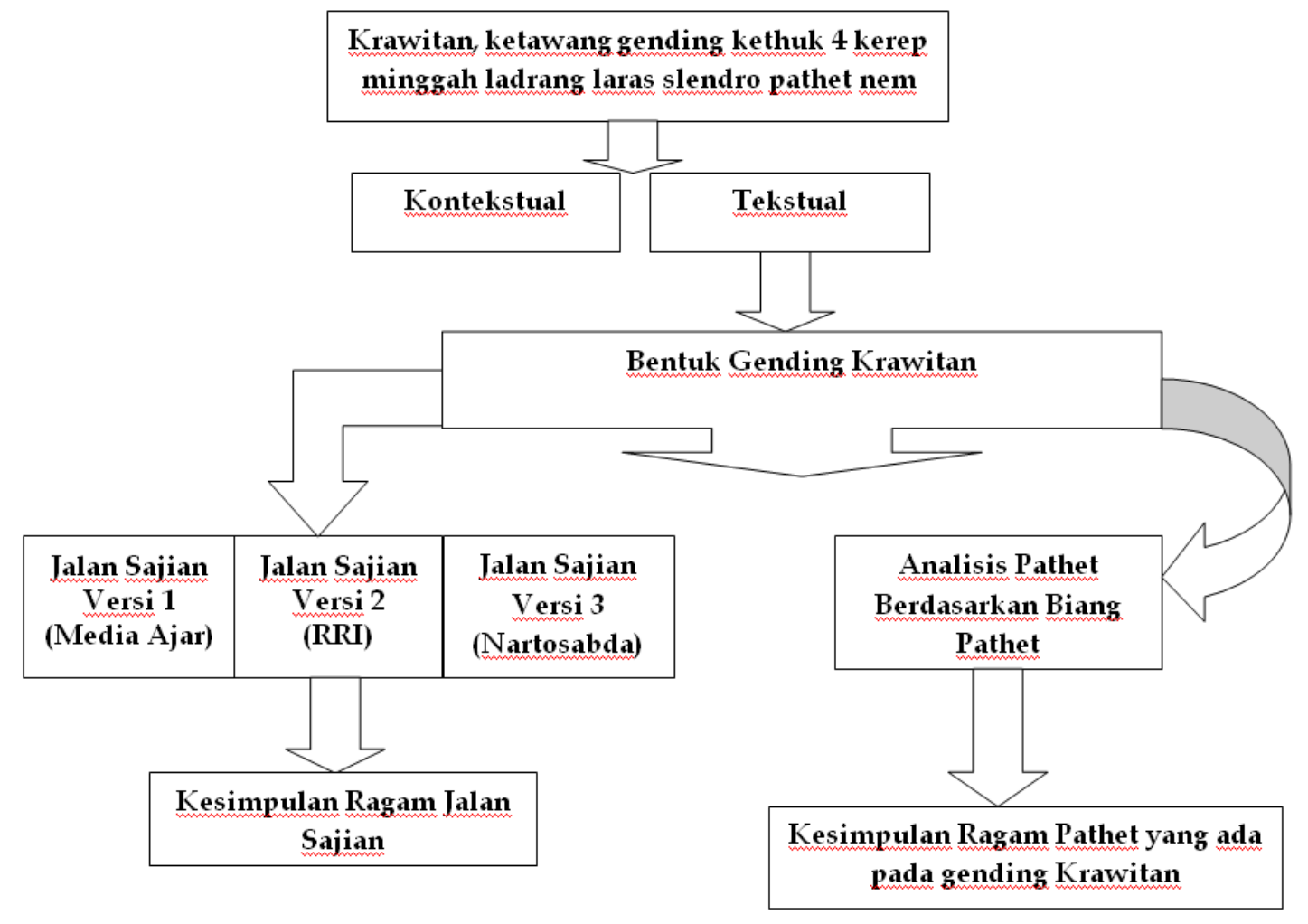

Bagan 1. Penggambaran Metode

(Sumber: Sigit Setiawan, 2021)

\section{Pembahasan}

\section{A. Bentuk Gending dan Notasi}

Bentuk gending secara sederhana, dapat diidentifikasi berdasarkan jumlah sabetan (pukulan) balungan yang terdapat pada setiap gatra di mana pada masing-masing gatra tertentu ditandai dengan adanya pukulan ricikan struktural seperti kethuk, kethuk kempyang, kenong, kempul, dan gong. Dari sana terdapat beberapa klasifikasi mengenai bentuk gending. Sebenarnya pula bentuk pada gending merupakan upaya yang dilakukan oleh para pengrawit dalam menandai kalimat lagu yang terepresentasi pada konsep padhang-ulihan, meskipun pada praktiknya ada gending yang secara alur melodi tidak mesti sejajar dengan letak pukulan kenong sebagai penanda padhang dan gong sebagai penanda ulihan. Sedikit pengertian padhang dan ulihan dalam konteks bahasa identik dengan istilah pertanyaan dan jawaban pada kalimat. Diskusi terkait bentuk dan kalimat lagu gending sebaiknya dilakukan pada konteks penelitian lain. Dalam konteks penelitian ini bentuk gending dimaknai sebagai penanda bahwa suatu gending telah memiliki tabuhan ricikan struktural yang ajeg. Untuk lebih jelas terkait pengertian bentuk gending setidaknya dapat membaca tulisan Martopangrawit (1969), Rahayu Supanggah (2007), dan Sri Hastanto ( 2009).

Gending yang dijadikan obyek penelitian adalah Krawitan, yang secara lengkap dapat dituliskan; Krawitan, ketawang gending kethuk 4 kerep minggah ladrangan. Hal tersebut menyiratkan bahwa nama gendingnya adalah Krawitan, bentuknya ketawang gending kethuk 4 kerep yang dilanjutkan gending bentuk ladrang. Bentuk ketawang gending menurut penulis adalah pemekaran bentuk dari bentuk ketawang, yang dalam setiap satu tabuhan gong terdiri dari dua tabuhan kenong, 
yang dalam satu gong terdapat enambelas sabetan balungan. Letak tabuhan kenong pada gatra kedua dan keempat sabetan balungan ke empat, sedangkan tabuhan gong terletak pada gatra keempat sabetan balungan keempat. Lihat skema bentuk ketawang sebagai berikut

Bentuk ketawang tersebut bila mekar menjadi bentuk ketawang gending kethuk 2 kerep menjadi seperti berikut.

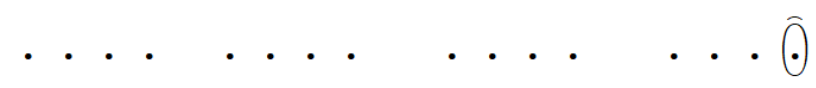

Bentuk ketawang gending kethuk 2 kerep di atas, berubah lebih besar menjadi bentuk ketawang gending kethuk 4 kerep seperti berikut.

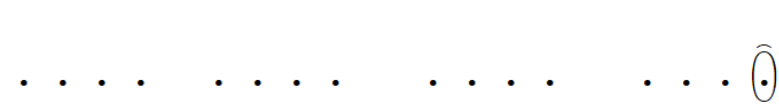

Bentuk terakhir inilah yang menjadi wadah Gending Krawitan, yang kemudian dilanjutkan (minggah) bentuk ladrang seperti berikut.

Seperti dibahas sebelumnya, bahwa gending ini memiliki beberapa cengkok gongan pada bagian merong. Ada beberapa perbedaan penulisan notasi Gending Krawitan dan seperti konvensinya, bahwa perbedaan penulisan notasi bukanlah masalah besar. Notasi pada posisi ini adalah representasi kerangka balungan gending itu sendiri. Kerangka balungan boleh berbeda tetapi pada persoalan garap bisa jadi memiliki kemiripan. Sebagai contoh pada kasus balungan garap cengkok mati puthut gelut slendro sanga berikut.

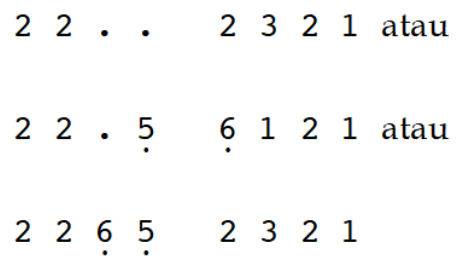

Meski notasi di atas tampak dalam wujud yang berbeda, pada ranah garap, notasi balungan tersebut tetap direalisasi menggunakan cengkok mati bernama puthut gelut. Lebih jauh terkait cengkok mati baca penelitian Nanang Bayu Aji (Aji 2019). Untuk itu, pada penelitian ini menggunakan satu versi notasi balungan versi notasi balungan Boston Village Gamelan (BVG) sebagai berikut. 


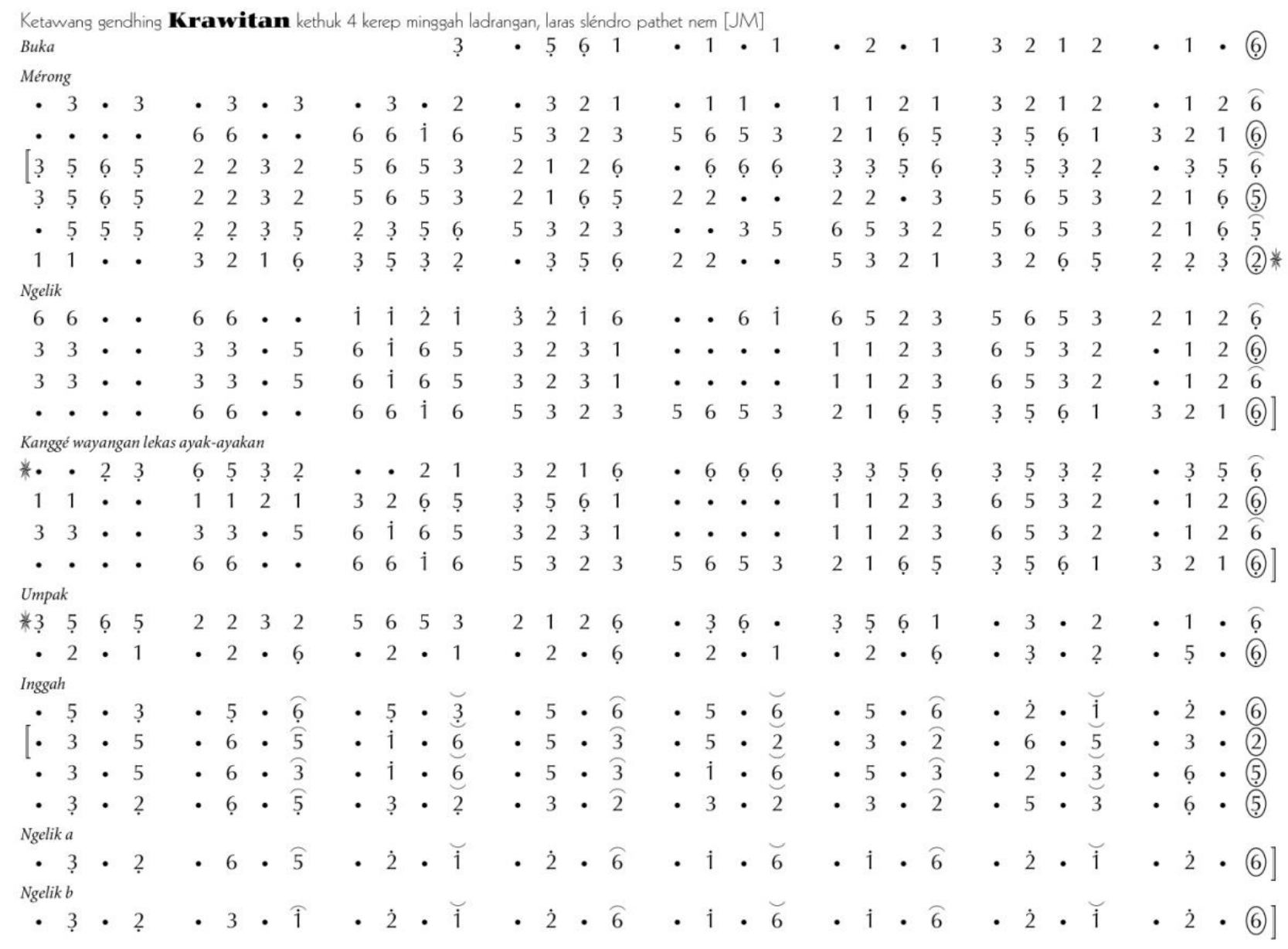

\section{B. Jalan Sajian}

Sebuah gending, ketika disajikan, akan mengalami siklus keterulangan, misalnya ketika kita mengamati seberapa sering gong ageng dalam sajian gending itu akan ditabuh, minimal secara bentuk, gending akan mengalamainya. Demikianlah jalan sajian setidaknya akan dimaknai. Jalan sajian yang dimaksud adalah bagaimana gending itu berjalan mulai dari awal (buka) hingga gending itu berhenti (suwuk). Di antara buka hingga suwuk tersebut, gending mengalami dinamika dalam hal musikal, seperti dalam konteks irama dia akan bermain pada beberapa wilayah irama seperti groprak, lancar, tanggung, dadi, wilet, dan rangkep. Kemudian dari konteks garap - dan bisa jadi ada unsur irama di dalamnya - gending dapat juga berhenti sementara (mandheg), alih pathet, alih laras, yang di dalam permainannya telah ada semacam trapesty/ anyaman yang terbentuk melalui konvensi-konvensi (Sukamso 2015). Sebagai contoh, dalam sajian irama dadi ladrang Wilujeng laras slendro pathet manyura, penggerong (kelompok vokalis pria) akan menafsir dengan menyajikan salisir, sebuah metrum tembang Jawa. Tentu yang sudah mendarah daging bagi hampir semua pengrawit adalah cakepan "Parabe Sang Smarabangun dst...". Namun hal tersebut tidak akan disajikan pada irama wilet, pada kasus Gending Wilujeng Alus, atau Ladrang Wilujeng yang disajikan dengan garap 
irama wilet, penggerong akan menggunakan cakepan gerongan tembang Macapat Kinanthi seperti pada teks "Nalikani ra ing dalu dstnya..". Visualisasi kasus gerongan tersebut, sekiranya mampu memberikan sedikit gambaran mengenai apa yang disebut dengan konvensi dalam sajian karawitan.

Pada konteks yang lain, kemapanan jalan sajian gending sering menjadi acuan dari "kebenaran jalan sajian". Kenapa demikian, karena sebenarnya secara konseptual, gending sangat dinamis untuk digarap, bahkan diluar koridor ketradisiannya. Sekali lagi, bahwa jalan sajian merupakan deskripsi gending itu berjalan dari awal sampai akhir dengan usaha untuk melengkapi detail garap secara umum - bukan secara detail permainan per ricikan pada gamelan. Untuk itu, penjelasan jalan sajian pada tulisan ini didasarkan pada sumber data Gending Krawitan yang digunakan sebagai sample pada tulisan ini.

Ada tiga versi jalan sajian yang dituliskan pada penelitian ini. Tiga versi tersebut dituliskan dan diperlihatkan perbedaannya. Perbedaan ini kemungkinan besar karena saling ngemong antara dalang dengan gendingnya sehingga tercapai kesesuaian. Ketersuaian inilah yang diharapkan dapat terjadi, misalkan ketepatan dalang menyelesaikan janturannya yang bersamaan dengan gong $u d h a r$ pasca sirepan. Pendapat yang lain, menyebutkan bahwa garap dari Ayak-ayak slendro manyura adalah versi garap pakeliran versi Mangkunegaran (PDMN), serta ada yang menyebutkannya garap gaya klasik pedesaan (Klaten?). Sedangkan buka rebab adalah ciri khas garap Kraton Surakarta. Tentu diskusi ini butuh data-data dan analisis yang lebih mendalam. Sayangnya, koridor penelitian ini tidak untuk mengungkap itu semua. Mungkin bisa dilakukan pada kesempatan yang lain, atau justru oleh peneliti yang lain.

\section{1) Versi I Sajian Gending Krawitan (Materi Ajar)}

Pada sajian versi ini, diawali dari Ayak-ayak slendro manyura. Sajian Ayak-ayak slendro manyura sengaja tidak dibahas pada tulisan ini karena memang fokus kajiannya adalah Gending Krawitan. Namun demikian, pada konvensi pakeliran tradisi, Ayak-ayak slendro manyura digunakan oleh dalang untuk mengeluarkan tokoh-tokoh yang diceritakan. Seperti adegan kerajaan Dwarawati misalnya ada tokoh seperti Prabu Kresna, Prabu Baladewa, Raden Samba, Raden Setyaki dan/ atau Patih Udawa ditambahkan dua tokoh parekan. Setelah semua tokoh siap atau sudah tancep, maka dalang akan memberi tanda melalui dhodhogan kothak yang menunjukan bahwa gending Ayak-ayak slendro manyura segara berakhir dan dilanjutkan Gending Krawitan.

Ketika sudah masuk gending Krawitan, sajian merong pertama disajikan dengan irama tanggung. Irama tanggung dengan laya sedheng disajikan hingga kenong pertama. Setelah tepat pada tabuhan kenong pertama, bersamaan dengan dalang ndhodhog/nggedhog kothak, irama tanggung secara perlahan disajikan semakin mencepat hingga puncaknya pada tabuhan gong merong pertama. Setelah itu, masuk merong kedua, setengah kenong pertama adalah fase peralihan dari irama tanggung seseg menuju irama dadi tepatnya pada dua gatra setelah pertengahan kenong pertama atau pada gatra 7 kenong pertama. Istilah irama "tanggung seseg" sengaja diketengahkan supaya ada perbedaan dengan irama tanggung sedheng atau tanggung tamban. Tanggung sedheng dan tamban sebagai tolok ukurnya, ricikan garap seperti gender barung, gender penerus, gambang, siter, dan rebab masih dapat bermain sesuai dengan vokabulernya, bersamaan dengan tabuhan saron penerus. Tanggung seseg dimaknai, ricikan garap yang dimaksud dapat bermain mbalung atau tidak bermain, karena sudah tidak efektif bila bermain sesuai vokabulernya, tetapi saron penerus masih dapat bermain seperti pola/ tekniknya dengan tempo yang cepat. Itulah kenapa pada fase peralihan atau angkatan menuju sirep ini statusnya masih irama tanggung. 
Kembali pada jalan sajian yang sudah menjadi irama dadi pasca peralihan menuju sirep. Untuk selanjutnya disajikan irama dadi. Adapun instrumen yang tetap ditabuh adalah rebab, kendang, gender, slenthem, suling, kenong, kethuk, dan gong ageng serta vokal sindhen yang juga mengurangi volumenya. Pada versi lain, sindhenan juga ikut tereliminasi. Perlu diketahui bahwa sirep secara umum adalah bentuk eliminasi dari permainan ricikan maupun volume tabuhan serta tempo dari yang "sebelumnya". Pada konteks pakeliran, semula gending disajikan utuh, artinya semua instrumen terlibat dalam sajian gending. Ketika sirep maka beberapa instrumen, seperti balungan - bahkan pada versi yang diteliti pada penelitian ini, pada versi 2, slenthem tidak bermain atau ikut sirep. Namun estetika sirep saat ini slenthem tetap bermain -, bonang barung dan penerus, tidak bermain. Praktis yang bermain saat sirepan ini adalah rebab, kendang, gender, dan ricikan struktural.

Sirepan yang disajikan pada irama dadi ini disajikan hingga merong keempat pasca sirep. Bila melihat notasi di atas, sajian Gending Krawitan pada bagian ngelik merong tidak disajikan - lihat keterangan pada notasi. Setelah udhar, tepat pada gong merong ke empat pasca sirep, kemudian dilanjutkan merong berikutnya yang juga sekaligus sebagai tempat peralihan dari merong menuju ladrang. Pada bagian peralihan ini, gatra satu hingga tiga, digunakan sebagai angkatan peralihan dari irama dadi ke irama tanggung, hingga tepat setelah kenong pertama masuk umpak inggah yakni pada balungan nibani. Masuk pada bagian ladrang disajikan dengan irama tanggung hingga kenong kedua. Setelahnya hingga pada setengah rambahan gong ketiga disajikan irama dadi. Setengah gong berikutnya pada gongan ladrang ketiga, digunakan sebagai peralihan menuju suwuk. Irama yang disajikan adalah dari irama dadi ke tanggung. Irama dadi ngampat pada gatra 5 dan 6 kemudian berubah menjadi irama tanggung pada gatra 8 dan 9 hingga gong. Kemudian sajian bertahan pada irama tanggung hingga kenong 3 ladrang gongan terakhir. Setelah itu menuju suwuknya, dua gatra terakhir menjadi irama dadi yang semakin melambat hingga gong terakhir bagian ladrang berakhir. Untuk lebih mendapatkan gambaran mengenai garap pakeliran, Sumarsam telah menjelaskan dalam bukunya berjudul "Memaknai Wayang dan Gamelan : Temu Silang Jawa, Islam, dan Global" (Sumarsam 2018). Di sana juga terdapat bahasan mengenai irama dalam gamelan.

Untuk memudahkan pemahaman bagian jalan sajian, maka di bawah ini diterakan mengenai simulasi jalan sajian yang akan ditambahkan visualisai irama yang digunakan pada sajian Krawitan dari Ayak-ayakan slendro manyura. Adapun data yang digunakan adalah Gending Krawitan materi ajar Jurusan Pedalangan ISI Surakarta. 


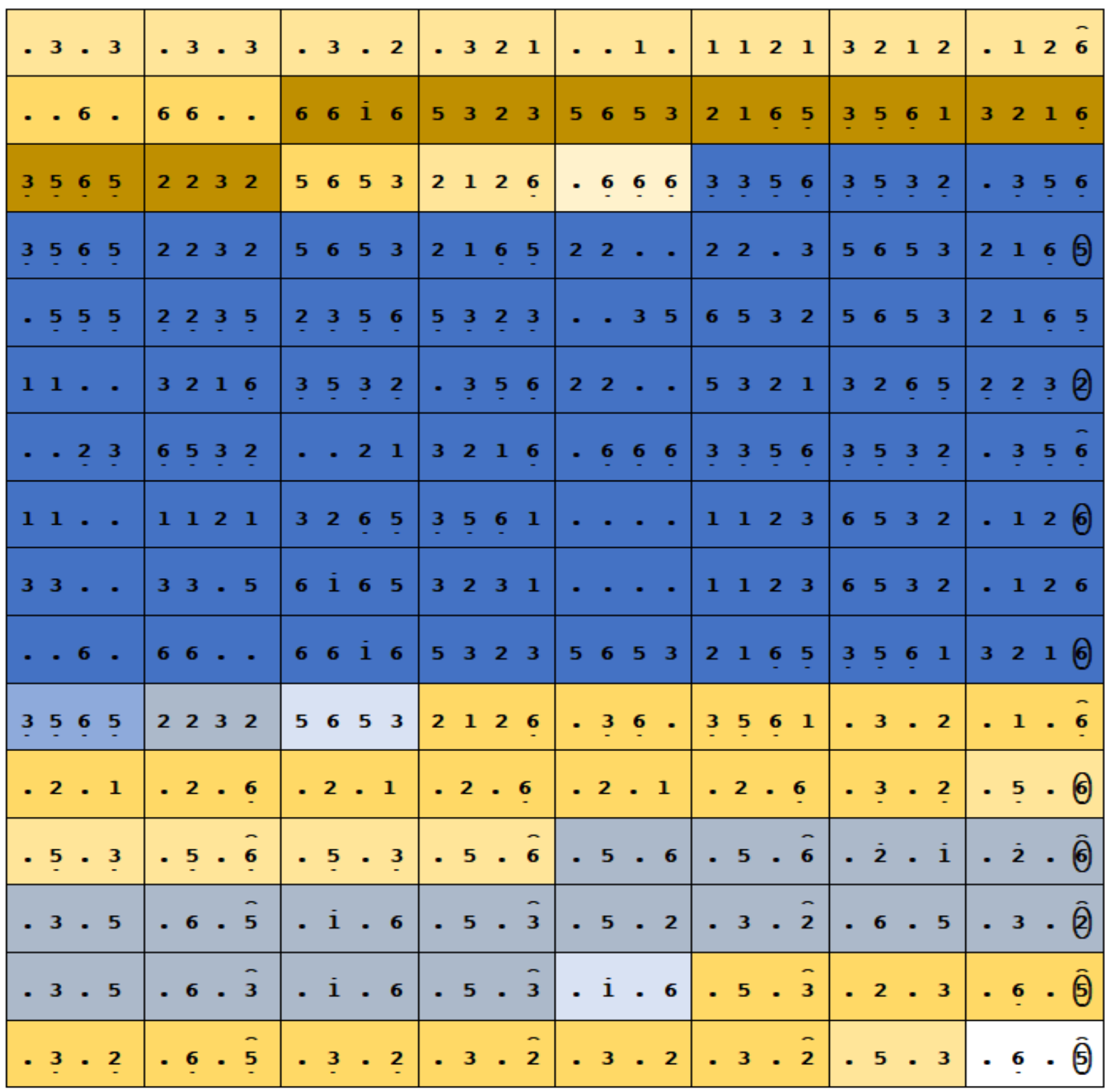

Gambar 2. Visualisasi Jalan Sajian

(Sumber: Sigit Setiawan, 2021)

Visualisasi warna di atas sebenarnya sebagai upaya untuk memberikan gambaran permainan irama pada sajian Gending Krawitan, mulai dari masuk merong setelah Ayak-ayak slendro manyura, masuk irama tanggung, sirep, udhar, peralihan ke ladrang - irama tanggung ke dadi - angkatan suwuk, dan suwuk. Berikut keterangan dari warna-warna sebagai penggambaran iramanya. 
Tabel 1 . Keterangan Visualisasi Jalan Sajian

(Sumber: Sigit Setiawan, 2021)

\begin{tabular}{|c|c|c|}
\hline No & Warna & Keterangan \\
\hline 1 & & $\begin{array}{c}\text { Irama tanggung tamban, ricikan garap masih dapat bermain dengan } \\
\text { nyaman }\end{array}$ \\
\hline 2 & & $\begin{array}{c}\text { Irama tanggung sedheng, ricikan garap masih dapat bermain dengan } \\
\text { nyaman tetapi lebih cepat dari warna no } 1\end{array}$ \\
\hline 3 & & $\begin{array}{c}\text { Irama tanggung seseg, ricikan garap tidak dapat bermain dengan } \\
\text { nyaman karena terlalu cepat, tetapi saron penerus masih dapat } \\
\text { bermain dengan cepat }\end{array}$ \\
\hline 4 & & Irama dadi bagian sirepan \\
\hline 5 & & Irama dadi udhar / irama dadi "normal" pakeliran \\
\hline 6 & & Irama dadi ngampat (mulai mencepat) dari irama "normal" \\
\hline 7 & & Irama dadi seseg / peralihan ke tanggung \\
\hline 8 & & Irama dadi sangat tamban suwvuk \\
\hline
\end{tabular}

\section{2) Versi 2 Sajian Gending Krawitan (RRI)}

Jalan sajian versi 2 ini diawali dari buka rebab. Pada bagian merong sebenarnya tidak jauh berbeda dengan sajian yang diawali Ayak-ayak. "Tidak jauh berbeda"nya adalah, bila sajian merong Krawitan dari Ayak-ayak slendro manyura, bagian merong ngelik tidak disajikan, tetapi bila buka rebab, merong ngelik disajikan. Hal ini tentu menjadi masuk akal, karena waktu ketika menampilkan tokoh wayang yang semula menggunakan gending Ayak-ayak, kemudian ketika tidak menggunakan Ayakayak, gendingnya digantikan merong Krawitan, yakni pada merong pertama hingga merong ke tujuh. Bagian merong ngelik atau gongan 4 dan 5, disajikan hingga kembali pada bagian merong kedua - lihat notasi.

Gending Krawitan diawali buka rebab, kemudian masuk irama tanggung hingga menjelang kenong pertama. Tepat setelah kenong pertama, merong pertama, merong disajikan irama dadi, menggunakan kendang kosek ketawang gending kethuk 4 kerep/ kendang kosek wayangan kethuk 2 kerep hingga dalang ndhodhog kothak pada kenong pertama merong ke tujuh. Setelah itu peralihan dari irama dadi ke tanggung hingga gong, yang kemudian sirep pada pertengahan kenong pertama merong gong kedua hingga irama berubah menjadi irama dadi saat sirep. Saat sirep ini, jalan sajian sama dengan versi dari Ayak-ayak atau bagian ngelik merong ketika sirep, tidak disajikan.

Sajian kemudian dilanjutkan menuju ladrang Krawitan. Perbedaannya pada bagian umpak inggah menuju gong digarap sesegan. Irama yang disajikan tanggung seseg hingga praktis yang bermain adalah kendang, balungan, bonang dan ricikan struktural selama dua gongan. Pada gong setelahnya tepat pada gatra dua, sigeg - seperti mandheg mendadak tetapi tidak berhenti - berubah dari irama tanggung seseg ke tamban, dan setelah kenong kedua menjadi irama wilet dengan menggunakan kendangan kosek wayangan alus. Irama wilet disajikan dua gongan atau dua gerongan. Lalu pada gongan gerongan terakhir inilah tepat pada tabuhan gong irama berubah menjadi irama dadi. Irama dadi setelah irama wilet ini kemudian pada kenong kedua berubah menuju irama tanggung, hingga gong. Setelah gong irama tanggung ini, disajikan lagi sesegan sebanyak satu rambahan. Setelah itu sajian suwuk seperti laiknya versi suwuk ladrang sajian dari Ayak-ayak slendro manyura. Untuk memudahkan pemahapan bagian jalan sajian, maka di bawah ini akan diterakan 
mengenai simulasi jalan sajian yang akan ditambahkan visualisasi irama yang digunakan pada sajian Gending Krawitan dari buka rebab.

\begin{tabular}{|c|c|c|c|c|c|c|c|}
\hline$\cdot 3 \cdot 3$ & $-3 \cdot 3$ & $\cdot 3 \cdot 2$ & - $\begin{array}{lll}3 & 2 & 1\end{array}$ & $-\quad-1$ & $\begin{array}{llll}1 & 1 & 2 & 1\end{array}$ & $\begin{array}{llll}3 & 2 & 1 & 2\end{array}$ & $-122 \hat{6}$ \\
\hline.-6. & 66. & 66 i 6 & $\begin{array}{llll}5 & 3 & 2 & 3\end{array}$ & $\begin{array}{llll}5 & 6 & 5 & 3\end{array}$ & $\begin{array}{llll}2 & 1 & 6 & 5\end{array}$ & $\begin{array}{llll}3 & 5 & 6 & 1\end{array}$ & $\begin{array}{llll}3 & 2 & 1 & 6\end{array}$ \\
\hline 3565 & 2232 & $\begin{array}{llll}5 & 6 & 5 & 3\end{array}$ & $\begin{array}{llll}2 & 1 & 2 & 6\end{array}$ & - 666 & $\begin{array}{llll}3 & 3 & 6\end{array}$ & $\begin{array}{llll}3 & 5 & 3 & 2\end{array}$ & -356 \\
\hline 3565 & 2232 & $\begin{array}{llll}5 & 6 & 5 & 3\end{array}$ & 2165 & 22 & $22 \cdot 3$ & $\begin{array}{llll}5 & 6 & 5 & 3\end{array}$ & 2116 \\
\hline-555 & 2235 & 2356 & 5323 &.$\quad 35$ & $\begin{array}{llll}6 & 5 & 3 & 2\end{array}$ & $\begin{array}{llll}5 & 6 & 5 & 3\end{array}$ & $\begin{array}{llll}2 & 1 & 6 & 5\end{array}$ \\
\hline $11-$ & $\begin{array}{llll}3 & 2 & 1 & 6\end{array}$ & $\begin{array}{llll}3 & 5 & 3 & 2\end{array}$ & -356 & 22 & $\begin{array}{llll}5 & 3 & 2 & 1\end{array}$ & $\begin{array}{llll}3 & 2 & 6 & 5\end{array}$ & 223 \\
\hline 66. & 66. & $\begin{array}{llll}\mathbf{i} & \mathbf{i} & \mathbf{2} & \mathbf{i}\end{array}$ & $\begin{array}{llll}3 & 2 & 1 & 6\end{array}$ & $6 i$ & $\begin{array}{llll}6 & 5 & 2 & 3\end{array}$ & $\begin{array}{llll}5 & 6 & 5 & 3\end{array}$ & $\begin{array}{llll}2 & 1 & 2 & 6\end{array}$ \\
\hline $33 \cdot$ & $33 \cdot 5$ & $\begin{array}{llll}6 & \mathrm{i} & 6 & 5\end{array}$ & $\begin{array}{llll}3 & 2 & 3 & 1\end{array}$ & $\cdot \cdot$ & $\begin{array}{llll}1 & 1 & 2 & 3\end{array}$ & $\begin{array}{llll}6 & 5 & 3 & 2\end{array}$ & . 126 \\
\hline $33 \cdot-$ & $33 \cdot 5$ & $\begin{array}{llll}6 & \mathrm{i} & 6 & 5\end{array}$ & $\begin{array}{llll}3 & 2 & 3 & 1\end{array}$ & $\cdot$ & $\begin{array}{llll}1 & 1 & 2 & 3\end{array}$ & $\begin{array}{llll}6 & 5 & 3 & 2\end{array}$ & $.12 \hat{6}$ \\
\hline-.6. & $66 .-$ & 66 i 6 & $\begin{array}{llll}5 & 3 & 2 & 3\end{array}$ & $\begin{array}{llll}5 & 6 & 5 & 3\end{array}$ & 2165 & $\begin{array}{llll}3 & 5 & 6 & 1\end{array}$ & $\begin{array}{llll}3 & 2 & 1\end{array}$ \\
\hline 3565 & 2232 & $\begin{array}{llll}5 & 6 & 5 & 3\end{array}$ & $\begin{array}{llll}2 & 1 & 2 & 6\end{array}$ & -66 & 3356 & 3532 & -356 \\
\hline 3565 & 2232 & $\begin{array}{llll}5 & 6 & 5 & 3\end{array}$ & $\begin{array}{llll}2 & 1 & 6 & 5\end{array}$ & 22 & 22 & 53 & 6 (5) \\
\hline-555 & 2235 & 2356 & 5323 &.$\quad 35$ & $\begin{array}{llll}6 & 5 & 3 & 2\end{array}$ & $\begin{array}{llll}5 & 6 & 5 & 3\end{array}$ & 21 \\
\hline
\end{tabular}

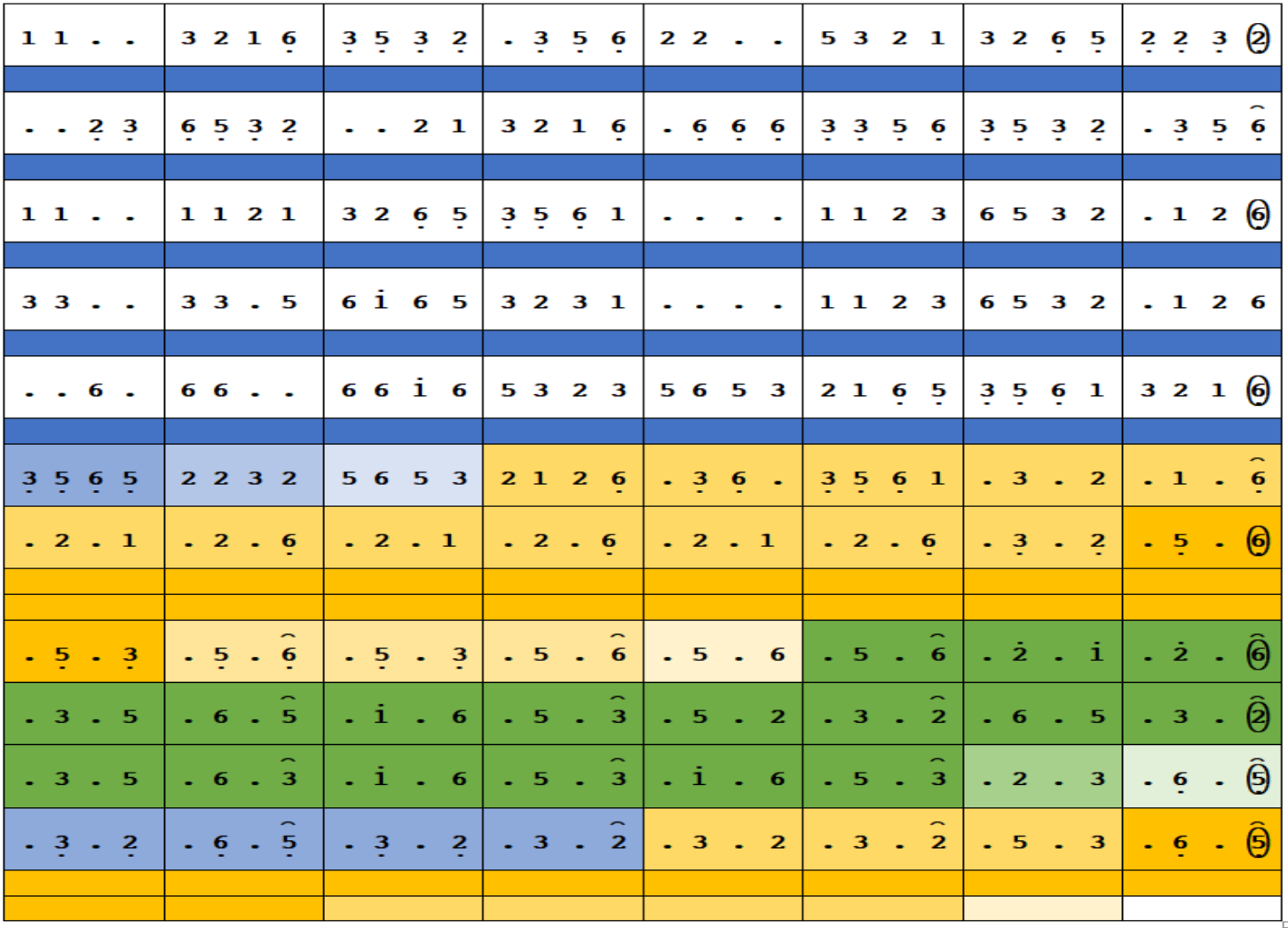

Gambar 3. Visualisasi Jalan Sajian

(Sumber: Sigit Setiawan, 2021) 
Berikut keterangan dari warna-warna sebagai penggambaran iramanya.

Tabel 2 . Keterangan Visualisasi Jalan Sajian (Sumber: Sigit Setiawan, 2021)

\begin{tabular}{|c|c|c|}
\hline No & Warna & Keterangan \\
\hline 1 & & $\begin{array}{c}\text { Irama tanggung tamban, ricikan garap masih dapat bermain dengan } \\
\text { nyaman }\end{array}$ \\
\hline 2 & & $\begin{array}{c}\text { Irama tanggung sedheng, ricikan garap masih dapat bermain dengan } \\
\text { nyaman tetapi lebih cepat dari warna no } 1\end{array}$ \\
\hline 3 & & $\begin{array}{c}\text { Irama tanggung seseg, ricikan garap tidak dapat bermain dengan } \\
\text { nyaman karena terlalu cepat, tetapi saron penerus masih dapat } \\
\text { bermain dengan cepat }\end{array}$ \\
\hline 4 & & Irama dadi bagian sirepan \\
\hline 5 & & Irama dadi udhar / irama dadi "normal" pakeliran \\
\hline 6 & & Irama dadi ngampat (mulai mencepat) dari irama "normal" \\
\hline
\end{tabular}

\begin{tabular}{|c|c|c|}
\hline 7 & Irama dadi seseg / peralihan ke tanggung \\
\hline 8 & Irama dadi sangat tamban suwuk \\
\hline 9 & Irama Wilet \\
\hline 10 & Ngampat dari wilet ke dadi \\
\hline 11 & Wilet seseg peralihan ke dadi \\
\hline
\end{tabular}

\section{3) Versi 3 Sajian Gending Krawitan (Nartosabda)}

Jalan sajian versi 3 atau versi Nartosabda ini sebenarnya tidak ada perbedaan mendasar apabila dibandingkan dengan versi 1 (Media Ajar) terutama pada bagian merong. Jalan sajian untuk bagian ladrang juga hampir sama dengan garap jalan sajian versi 2. Perbedaannya yakni tempat sesegannya. Jadi pada versi ini, yang digarap sesegan atau digarap tanggung seseg adalah pada bagian umpak inggah, yakni setelah kenong pertama merong terakhir. Tepat setelah gong umpak inggah, irama melambat dari tanggung ke dadi, setelah masuk kenong dua, irama tamban hingga berubah menjadi irama wilet. Untuk sajian suwuknya, tepat setelah gong kedua irama wilet, pada gatra ketiga sudah menjadi irama tanggung dan selanjutnya suwuk layaknya versi 1 dan versi 2. Suwuk versi seperti ini, akan menjadi unik bila dipandang dari versi 1 dan 2. Karena menurut dua versi awal angkatan suwuk baik dari irama dadi maupun irama wilet, selalu diawali dari kenong kedua.

Keunikan lainnya, pada versi ketiga ini, adalah pada angkatan sirep merong pertama. Bila versi 1 dan 2 konsisten menggunakan tahapan irama hingga irama tanggung seseg. Versi ketiga ini menggunakan irama lancar. Kenapa irama lancar, karena tingkat kepadatan gatra yang berubah. Ada modifikasi gatra yang semula tersusun satu gatra menggunakan balungan mlaku atau satu gatra terisi penuh sabetan balungan, pada versi ini memadat menjadi balungan nibani. Perubahan ini selaras dengan perubahan irama, di mana apabila dilihat dari tabuhan saron penerus tidak mungkin untuk menyajikan dengan pola yang sama pada irama tanggung versi 1 dan 2 . Untuk lebih jelasnya lihat perubahan balungan berikut ini. 
Versi 1 Media Ajar dan 2 RRI

\begin{tabular}{|c|c|c|c|c|c|c|c|}
\hline $.3 \cdot 3$ & . 3 & . 3 & - 321 & - 1 & $\begin{array}{llll}1 & 1 & 2 & 1\end{array}$ & $\begin{array}{lll}32 & 1\end{array}$ & $.12 \hat{6}$ \\
\hline . 6 & 66 & 66 i 6 & $\begin{array}{llll}5 & 3 & 2 & 3\end{array}$ & 565 & 2165 & $\begin{array}{llll}3 & 5 & 6 & 1\end{array}$ & $\begin{array}{llll}3 & 2 & 1 & 6\end{array}$ \\
\hline
\end{tabular}

Versi 3 Nartosabda

\begin{tabular}{|c|c|c|c|c|c|c|c|}
\hline$\cdot 3 \cdot 3$ & $\cdot 3 \cdot 3$ & $\cdot 3 \cdot 2$ & - 321 &. .1. & $\begin{array}{llll}1 & 1 & 2 & 1\end{array}$ & $\begin{array}{llll}3 & 2 & 1 & 2\end{array}$ & $.12 \hat{6}$ \\
\hline .6 & 66 & $66 \mathrm{i} 6$ & $.5 \cdot 3$ & $.5 \cdot 3$ & . $2 \cdot 1$ & $.3 \cdot 2$ & .1 .6 \\
\hline
\end{tabular}

Versi 1 Media Ajar dan 2 RRI

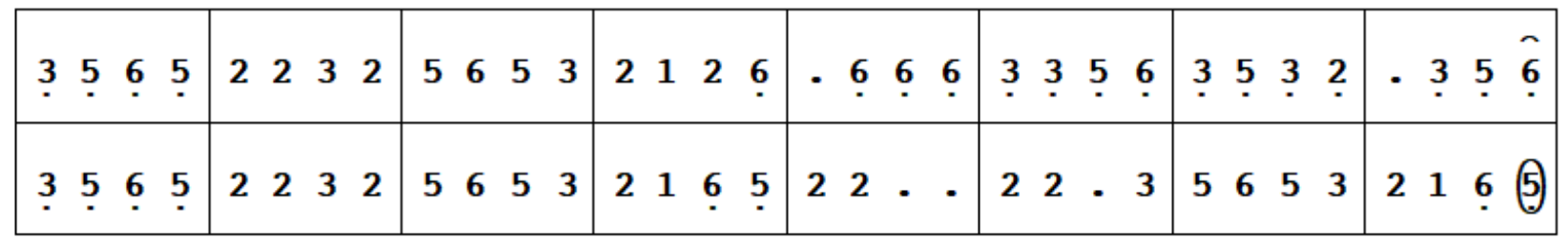

Versi 3 Nartosabda

\begin{tabular}{|c|c|c|c|c|c|c|c|}
\hline$-3 \cdot 5$ & $\cdot 3 \cdot 2$ & $\cdot 5 \cdot 3$ & $\cdot 5 \cdot 6$ & .66 & 3356 & $\begin{array}{llll}3 & 5 & 3 & 2\end{array}$ & .356 \\
\hline 35 & 2232 & $\begin{array}{llll}5 & 6 & 5 & 3\end{array}$ & $\begin{array}{llll}2 & 1 & 6 & 5\end{array}$ & 22 & $22 \cdot 3$ & $\begin{array}{llll}5 & 6 & 5 & 3\end{array}$ & $\begin{array}{llll}2 & 1 & 6 & (5)\end{array}$ \\
\hline
\end{tabular}

Apabila melihat perbandingan di atas, perubahan balungan - dan semestinya juga perubahan irama dari tanggung ke lancar - terjadi pada gatra 12 hingga 16 gong pertama dan gatra 1 hingga gatra 4 merong kedua. Konsekuensinya, perubahan menjadi irama dadi juga mundur yakni pada gatra ke 8 baru menjadi irama dadi. Hal ini masuk akal karena konsep perubahan irama yang mengalir dalam karawitan Jawa, ketika irama lancar baru berhenti pada gatra 4 merong kedua, maka gatra selanjutnya, yaitu gatra 5, 6, dan 7, menjadi gatra peralihan irama lancar ke tanggung hingga ke dadi. Tentu ini berbeda dengan irama tanggung ke dadi saja, yang cukup berubah pada gatra 5 dan 6 , kemudian gatra ke 7 sudah menjadi irama tanggung. Konsep angkatan sirep seperti ini, oleh Purnomo, salah satu pengrawit dan juga mumpuni terutama ketika sebagai pengendang wayang disebut dengan gerba atau digerba. Gerba dalam pengertian dipadatkan gatranya hingga terjadi perubahan irama. Kesan musikal yang hadir menjadi sangat santak dan lebih gagah. Belum dapat dipastikan garap seperti ini lahir darimana. Namun Purnomo menjelaskan bahwa ini adalah garap "Cara Nggombang" (Wawancara, Gathot Purnomo, di Surakarta, 2021). Gombang, adalah salah satu daerah Boyolali yang sedari dulu hingga sekarang terkenal melahirkan pengrawit yang handal. Pengrawit-pengrawit tersebut sering terlibat pada pertunjukan maupun rekaman dalang-dalang terkenal seperti $\mathrm{Ki}$ Nartosabda, dan Ki Anom Suroto. Sebut saja, pengendang Ki Anom Suroto dan Ki Nartosabda 
dahulu, katakan pada era 80 dan 90an, adalah Srimara dan Srikaya yang juga kebetulan putra daerah Gombang. Kemungkinan besar versi ini lahir dan disajikan oleh Nartosabda karena hal tersebut dipengaruhi oleh garap karawitan para pengrawit Gombang ini. Mohon dicatat pula, bahwa pada masa kejayaannya, Nartosabda juga melibatkan banyak pengrawit dari daerah Gombang dalam setiap pertunjukannya. Jadi pada konteks "gaya sirepan" ini, Nartosabdalah yang kemungkinan besar mendapat pengaruh dari kreativitas pengrawit hebat dari Gombang.

Terkait dengan istilahnya, gerba, pendapat berbeda diberikan oleh Sri Eko Widodo. Menurut Widodo, "gaya sirepan ala Gombang" ini, lebih dekat dengan istilah racut (Wawancara, Sri Eko Widodo, Surakarta, 2021). Kata ini, menurutnya, asosiatif dengan kata perjalanan kata irama dalam arti menyempit. Artinya bila irama dalam Gending Krawitan ini terjadi perubahan irama dari irama dadi ke tanggung dan ke lancar, maka penjelasan Widodo lebih logis, disebabkan ada perjalanan irama yang semakin menyempit - bila dilihat dari tabuhan saron penerus. Namun demikian, dalam penelitian ini belum dapat dipastikan bahwa "gaya sirepan" yang dimaksud, secara istilah disebut gerba atau racut.

Pembahasan jalan sajian mulai dari versi 1, versi 2 , dan versi 3 di atas setidaknya menyiratkan beberapa hal sebagai berikut,

a) Terdapat dua versi untuk mengawali Gending Krawitan dalam konteks pakeliran, yaitu dapat dari buka rebab dan dari Ayak-ayak slendro manyura.

b) Bila dari buka rebab, merong ngelik disajikan ketika irama dadi yang tidak sirep, ketika sirep, merong ngelik ini tidak disajikan.

c) Ada dua versi terkait dengan angkatan sirep. Pertama yaitu versi RRI dan Media ajar yang secara irama masih pada irama tanggung, dan versi kedua yaitu versi Nartosabdan yang kemungkinan dipengaruhi oleh para pengrawit dari Gombang. Maka versi kedua ini disebut sebagai sirepan versi "ngGombang". Versi terakhir ini tidak hanya pada tataran irama tanggung, tetapi menjadi irama lancar. Maka beberapa versi menyebutnya sebagai sirepan gerba atau sirepan racut.

d) Ladrang dapat disajikan dalam dua irama pokok yaitu irama dadi dan irama wilet.

e) Bila digarap irama dadi, maka cenderung sajian tidak menggunakan sesegan.

f) Bila digarap sesegan, maka cenderung digarap irama wilet.

g) Poin 5 dan 6 menjadi dapat dipahami, bila menggunakan tolok ukur dinamika karawitan klasik semisal padhang-ulihan. Untuk memberi kesan wilet supaya lebih terasa, maka pada bagian ladrang atau umpak inggah dapat digarap seseg.

h) Untuk suwuk, bila digarap pada irama dadi, maka perjalanannya mengalir, tetapi bila digarap irama wilet, pada akhir sajian juga dapat menggunakan sesegan hingga suwuk tamban.

\section{Analisis Pathet}

Sebagai dasar kerja analisis maka perangkat pathet-nya Sri Hastanto yang menyatakan bahwa kita dapat membuktikan gending A ini benar berpathet $\mathrm{X}$, yang dalam konteks penelitian ini berarti gending Krawitan, - apakah benar - berpathet nem. Penulis sadar, agak berlebihan memang, bila tulisan ini adalah ajang untuk menguji kebenaran pathetnya Sri Hastanto. Untuk itu, penulis sengaja meminjam karya monumental Sri Hastanto tersebut sebagai perangkat analisis Gending Krawitan dengan argumentasi, bahwasannya keniscayaan seorang pengrawit mengerti apa itu pathet. Mengerti equifalen dengan "dapat menafsirkan dengan benar" bukan mengerti dalam konteks “dapat menjelaskan secara verbal”. Maka jelas sudah, bahwa perangkat analisis yang digunakan ini 
adalah tepat guna. Langkah menganalisa frasa dan pathet berdasarkan biang pathet ini guna mengeksplanasi frasa dan pathetnya Gending Krawitan.

Eksplanasi Sri Hastanto mengenai pathet ada alat ukur untuk mengidentifikasi pathet pada suatu gending. Alat ukur inilah yang oleh Hastanto disebut dengan "biang pathet", yang kemudian dianalogikan dengan biang parfum atau biang makanan, sedikit porsi tetapi berpengaruh besar. Analisis pathet menafsirkan dalam untaian frasa atau kalimat lagu. Betul memang terdapat gending yang sejajar antara gatra dan frasa - dan Gending Krawitan adalah satu yang teridentifikasi terdapat kesejajaran gatra dan frasa, yaitu frasa yang hadir minimal terdiri dari dua gatra - , tetapi tidak semua gending demikian. Untuk itu, dalam menganalisis gending Krawitan dilengkapi dengan analisis pathet berdasarkan frasanya. Sedangkan apa itu biang pathet, selain dapat membaca pada buku Sri Hastanto (2009), dapat dilihat pada penjelasan berikut mengenai apa itu biang pathet.

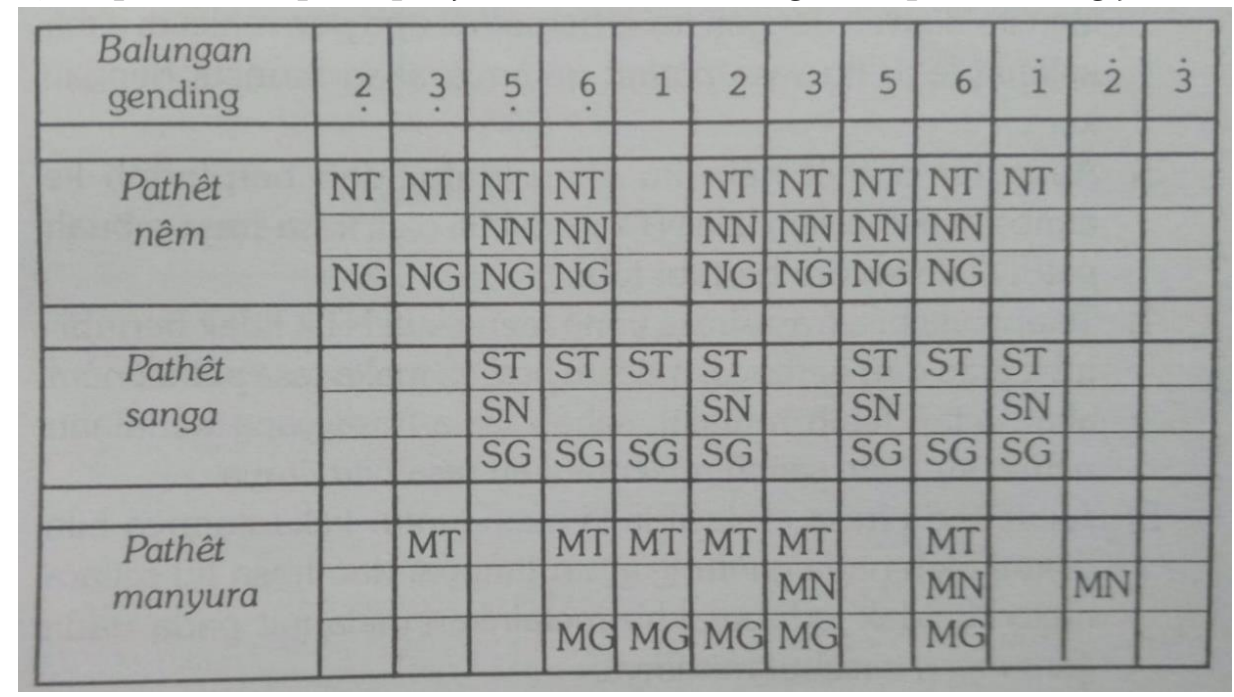

Gambar 4. Biang Pathet

(Sumber: Sri Hastanto, 2009)

Sebelum masuk pada tahap analisis, perlu disampaikan simbil-simbol pada biang pathet di atas. Simbol yang ada pada biang pathet, digunakan untuk menunjukan frasa-frasa dalam Gending Krawitan. Berikut adalah makna dari simbol-simbol dalam biang pathet Sri Hastanto.

- NT : Frasa Turun Pathet Nem atau Nem Turun

- NN : Frasa Turun Pathet Nem atau Nem Naik

- NG : Frasa Gantung Pathet Nem atau Nem Gantung

- ST : Frasa Turun Pathet Sanga atau Sanga Turun

- SN : Frasa Turun Pathet Sanga atau Sanga Naik

- SG : Frasa Gantung Pathet Sanga atau Sanga Gantung

- MT : Frasa Turun Pathet Manyura atau Manyura Turun

- MN : Frasa Turun Pathet Manyura atau Manyura Naik

- MG : Frasa Gantung Pathet Manyura atau Manyura Gantung

Sedangkan apa yang dimaksud dengan balungan gending adalah ambitus suara manusia rata-rata ketika memvokalkan nada-nada slendro. Maka dituliskan mulai dari nada 2 ageng hingga 3 alit. Bila dituliskan maka balungan gending dapat tersusun dari nada-nada sebagai berikut.

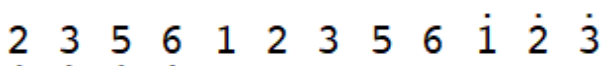


Setelah mengetahui simbol-simbol dan susunan nada untuk menyusun kalimat lagu, penjelasan pisau bedah ini belum selesai. Hastanto memaparkan bahwa pada biang pathet terdapat formula yang tumpang tindih. Hal tersebut menunjukan bahwa pembentuk frasa-frasa yang memberi kekuatan pada masing-masing pathet tidak sepenuhnya murni, tetapi saling berkaitan. Untuk itulah, penelitian ini sebenarnya menjawab pertanyaan mengapa dalam satu gending tertentu diisi oleh campuran pada masing-masing pathet. Kemudian, bagaimana gending dapat ditentukan bahwa satu gending berpathet nem/ sanga/ manyura? Menurut Hastanto, berdasarkan hasil investigasinya memaparkan bahwa pathet yang dominanlah yang digunakan sebagai label pathet pada satu gending. Dominan di sini tidak mesti berjumlah banyak, tetapi penempatan frasanya juga berpengaruh, misalkan pada awal dan akhir kalimat lagu gending. Meski gending dipenuhi frasa pathet $\mathrm{X}$ tetapi pada bagian seleh berat/ antebnya menggunakan frasa pathet $\mathrm{Y}$, maka besar kemungkinan bahwa gending tersebut tetap berpathet $Y$. Selain itu, Hastanto juga menyatakan bahwa frasa-frasa itu terbagi menjadi tiga jenis, yaitu frase eksklusif, frasa gantungan ekslusif, dan frasa yang tidak eksklusif. Frasa eksklusif adalah frasa di mana hanya pathet itulah yang memiliki. Frasa gantungan eksklusif dapat dikatakan sama dengan frasa ekslusif tetapi mewujud pada struktur balungan atau realisasi garapnya digantung. Frasa tidak eksklusif adalah frasa yang hadir pada semua pathet, dan cara menentukan statusnya pada pathet apa, tergantung pada mitra-mitra frasa pathet yang mengelilinginya (Hastanto, 2009 : 144-145).

Untuk memperkuat posisi Gending Krawitan dilihat dari paradigma pathetnya, maka pendapat Hastanto mengenai gending dan pathet layak untuk dituliskan. Gending dan pathet, menurut Hastanto, setidaknya ada tiga klasifikasi. Pertama adalah gending berpathet murni. Murni karena pada aplikasinya, para pengrawit tidak pernah mempermasalahkan pathetnya. Setidaknya para pengrawit tidak pernah kebingungan menggarap gending yang berpathet murni ini dari segi pemilihan vokabuler garapnya. Kedua adalah klasifikasi gending yang mengandung frasa-frasa "tidak seperti biasanya". Artinya meski label gending tersebut berpathet X tetapi pada perjalanan frasanya tidak dipenuhi frasa pathet $X$. Namun gending tersebut masih menggolongkan dirinya pada pathet $\mathrm{X}$ bukan pathet $\mathrm{Y}$. Ketiga, adalah gending dengan klasifikasi kontroversial. Disebut kontroversial karena label pathet pada gending tidak sama dengan aplikasi garapnya. Sehingga ketika gending ini disajikan pada laras yang lain, katakanlah laras pelog, maka gending ini menjadi lebih enak digarap. Bahkan lebih popular dibanding laras dan pathet awalnya yang slendro.

Gending Krawitan, apabila ditinjau dari klasifikasi gending berdasarkan pathet di atas, termasuk dalam kategori kedua, yakni gending yang mengandung frasa-frasa tidak seperti biasanya (pathet nem), tetapi masih dirasakan berpathet nem kuat. Setidaknya testimoni mengenai hal ini disampaikan pula oleh pengrawit hebat seperti Suwito Radyo, Sukamso, dan Suraji (Wawancara, Surakarta, 2021). Mereka sepakat bahwa Gending Krawitan adalah gending dengan kompleksitas garap, dan tentunya juga kompleksitas pathet, meski Gending Krawitan ini berlabel pathet nem. Jadi, jelas posisinya, bahwa kompleksitas garap sepadan dengan kompleksitas pathet (Wawancara, Suraji, 2021, di Surakarta).

Cara kerja analisis pathet yang berdasar pada, balungan gending, biang pathet, frasa/ kalimat lagu dilakukan pada setiap gongan merong dan gongan ladrang Gending Krawitan. Setiap gong merong terdiri dari 8 frasa, sedangkan setiap gong ladrang terdiri dari 4 frasa. Masing-masing frasa pada setiap gong merong dan ladrang akan dianalisis. Berikut abstraksi dari bagian-bagian yang dianalisis. 


\begin{tabular}{|c|c|c|c|c|c|c|c|c|}
\hline$\cdot 3 \cdot 3$ & $\cdot 3$ & - 3 & $\cdot 3 \cdot 2$ & - 321 & . $\cdot 1$ & $\begin{array}{llll}1 & 1 & 2 & 1\end{array}$ & $\begin{array}{llll}3 & 2 & 1 & 2\end{array}$ & - $12 \hat{6}$ \\
\hline \multicolumn{3}{|c|}{ Frasa 1 (F1) } & \multicolumn{2}{|c|}{ Frasa 2 (F2) } & \multicolumn{2}{|c|}{ Frasa 3 (F3) } & \multicolumn{2}{|c|}{ Frasa $4(\mathrm{~F} 3)$} \\
\hline \multicolumn{3}{|c|}{ NG/MG } & \multicolumn{2}{|c|}{ ST/MT } & \multicolumn{2}{|c|}{ SG/MG } & \multicolumn{2}{|c|}{ NN/MN } \\
\hline .6. & 66 & $\cdot \cdot$ & $6 \quad 6 i \quad 6$ & $\begin{array}{llll}5 & 3 & 2 & 3\end{array}$ & $\begin{array}{llll}5 & 6 & 5 & 3\end{array}$ & $\begin{array}{llll}2 & 1 & 6 & 5\end{array}$ & $\begin{array}{llll}3 & 5 & 6 & 1\end{array}$ & $\begin{array}{llll}3 & 2 & 1 & 6\end{array}$ \\
\hline \multicolumn{3}{|c|}{ Frasa 5 (F5) } & \multicolumn{2}{|c|}{ Frasa $6(\mathrm{~F} 6)$} & \multicolumn{2}{|c|}{ Frasa 7 (F7) } & \multicolumn{2}{|c|}{ Frasa 8 (F8) } \\
\hline \multicolumn{3}{|c|}{ NG/SG/MG } & \multicolumn{2}{|c|}{ NT/MT } & \multicolumn{2}{|c|}{ NT } & \multicolumn{2}{|c|}{$\mathrm{NT} / \mathrm{ST} / \mathrm{MT}$} \\
\hline
\end{tabular}

Wujud penulisan analisis adalah sebagai berikut.

\begin{tabular}{|c|c|c|c|c|c|c|c|}
\hline$\cdot 3 \cdot 3$ & $\cdot 3 \cdot 3$ & . $3 \cdot 2$ & . $\begin{array}{lll}32 & 1\end{array}$ & . . 1 & $\begin{array}{llll}1 & 1 & 2 & 1\end{array}$ & $\begin{array}{llll}3 & 2 & 1 & 2\end{array}$ & - $12 \hat{6}$ \\
\hline \multicolumn{2}{|c|}{ NG/MG } & \multicolumn{2}{|c|}{ ST/MT } & \multicolumn{2}{|c|}{ SG/MG } & \multicolumn{2}{|c|}{$\mathrm{NN} / \mathrm{MN}$} \\
\hline. .6. & 66 & $66 \mathrm{i} 6$ & $\begin{array}{llll}5 & 3 & 2 & 3\end{array}$ & $\begin{array}{llll}5 & 6 & 5 & 3\end{array}$ & $\begin{array}{llll}2 & 1 & 6 & 5\end{array}$ & $\begin{array}{llll}3 & 5 & 6 & 1\end{array}$ & $\begin{array}{llll}3 & 2 & 1 & 6\end{array}$ \\
\hline
\end{tabular}

Masing-masing gong merong dan ladrang, setelah dianalisis, akan diklasterisasi kekuatan pathetnya. Dari sana, kemudian tampak bahwa Gending Krawitan ini memang sepantasnya berpathet nem. Penulisan Frasa akan disingkat menjadi simbol F saja dan urutan setiap frasa pada setiap gongan ditulis menggunakan angka 1 hingga 8. Maka bila terdapat tulisan F1 maka dimaknai "Frasa 1", begitu pula seterusnya.

Berikut adalah pembahasan analisis pathetnya.

Merong Pertama

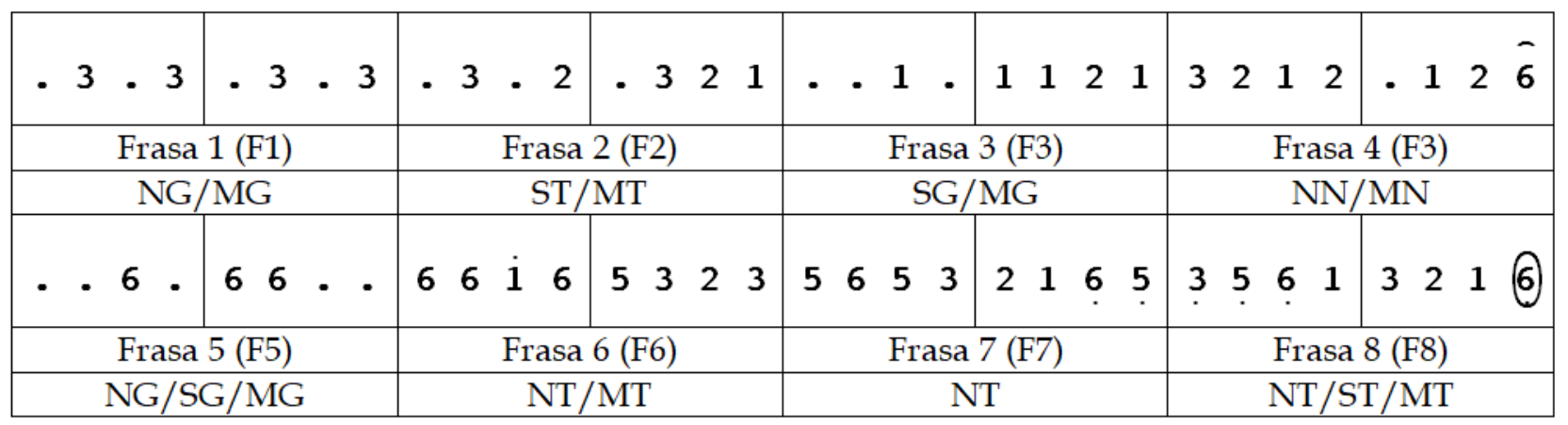

Analisis pathet di atas menemukan fakta frasa pathet sebagai berikut. F1 adalah berpotensi pathet nem dan manyura, F2 berpotensi berpathet sanga dan manyura, F3 berpathet sanga dan manyura, F4 berpathet nem dan manyura. F5 berpotensi pathet nem, sanga, dan manyura, F6 berpotensi pathet nem dan manyura, F7 berkekuatan frase ekslusif nem, dan F8 berpotensi nem, sanga, manyura. Bila dilihat potensi pathet nem berada pada wilayah F1, F4, F5, F6, F7, dan F8 dengan frase eksklusif pada F7. Dari sana, frasa nem, tidak terlalu mendominasi dari F1 hingga F6. Pada frasa berikutnya, yakni F7, menunjukan frasa eksklusif pathet nem, yang ditutup dengan frasa campuran atau F8. Frasa terakhir ini meski berpotensi frasa campuran, tetapi keberadaannya tetap dipengaruhi oleh frasa nem. Kesimpulan untuk merong pertama ini adalah, bahwa frasa pathet nem belumlah dominan, meski menampakan diri pada akhir frasa gong merong pertama ini. 
Merong Kedua

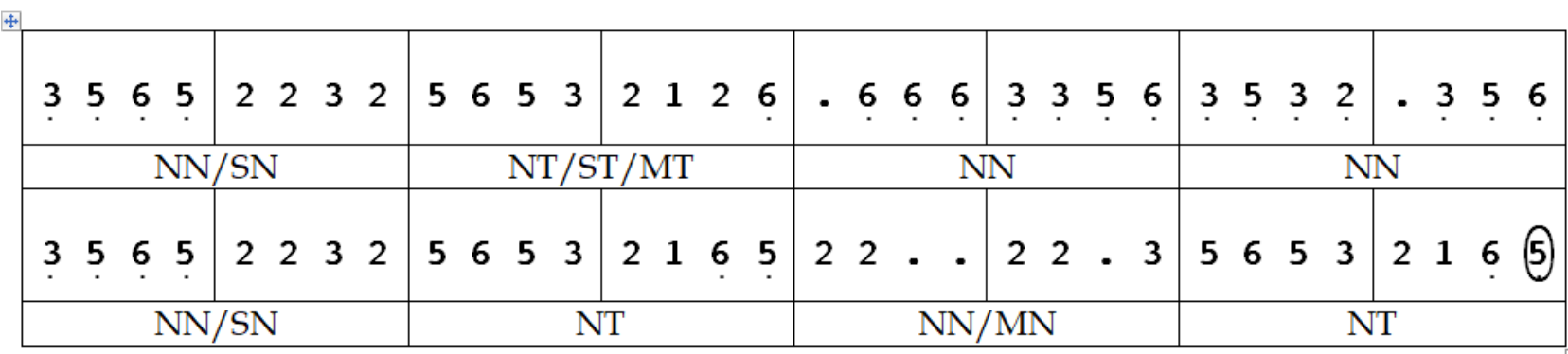

Analisa di atas menunjukan bahwa frasa eksklusif pathet nem nampak kuat dengan ditunjukan pada F3, F4, F6, F8. Menjadi semakin tampak kuat karena ada frasa eklusif yang keberadaannya berada pada akhir kalimat lagu atau gong merong kedua ini. Frasa lain, yang juga berpotensi berpathet nem dan sanga seperti F1, F2 dan F5 menjadi hambar atmosfir pathetnya karena didominasi oleh kekuatan pathet nem yang telah ditunjukan pada frasa yang lain pada merong ini. Penulis menyimpulkan bahwa merong kedua ini, dominan berpathet nem.

Merong Ketiga

\begin{tabular}{|c|c|c|c|c|c|c|c|}
\hline - 555 & 2235 & 2356 & 5323 & . . 35 & $\begin{array}{llll}6 & 5 & 3 & 2\end{array}$ & $\begin{array}{llll}5 & 6 & 5 & 3\end{array}$ & $\begin{array}{llll}2 & 1 & 6 & 5\end{array}$ \\
\hline \multicolumn{2}{|c|}{ NG/SG } & \multicolumn{2}{|c|}{ NT/MT } & \multicolumn{2}{|c|}{ NT/ST/MT } & \multicolumn{2}{|c|}{ NT } \\
\hline 11 & 32 & 35 & -356 & 22 & $\begin{array}{llll}5 & 3 & 2 & 1\end{array}$ & 326 & $\begin{array}{llll}2 & 2 & 3 & 2\end{array}$ \\
\hline \multicolumn{2}{|c|}{ NT/ST/MT } & \multicolumn{2}{|c|}{$\mathrm{NN}$} & \multicolumn{2}{|c|}{ ST/MT } & \multicolumn{2}{|c|}{ NT } \\
\hline
\end{tabular}

Merong ketiga seperti tertulis pada tabel analisa di atas tampak bahwa frasa ekslusif berbicara pada F4, F6, dan F8. Frasa lainnya, seperti F1 berpotensi untuk pathet nem dan sanga serta F2 pada pathet nem dan manyura. Kemudian F3 dan F5 berpotensi nem, sanga, dan manyura. F1 dan F2 tidak dapat bernuansa sanga dan manyura karena melihat gong merong kedua yang bernuansa frasa nem eksklusif. F3 meski dapat bernuansa nem, sanga, manyura, akhirnya juga melemah karena frasa eksklusif pada F4. F5 yang sama potensinya dengan F3 juga tidak berdaya karena F6 bernuansa frasa eksklusif nem. Demikian halnya pada F7 juga tidak dapat berkembang ke frasa sanga atau manyura karena adanya frasa eksklusif pada akhir lagu merong ketiga ini. Kesimpulannya, pada merong ketiga ini, jelas bahwa pathet nem sangat dominan.

Sebelum menganalisa pada merong ngelik keempat dan kelima, maka penulis perlu mengingatkan pada bahasan jalan sajian. Bahwasannya, ngelik ini, bila sajian Gending Krawitan disajikan dari Ayak-ayak slendro manyura, maka praktis tidak disajikan. Pun, ketika sajian diawali buka rebab, sajian ngelik ini disajikan pada irama dadi yang tidak sirep. Ketika terjadi pengulangan, pada saat sirep dan sajian kembali ke awal (merong kedua) bagian ngelik ini juga tidak disajikan. Artinya baik buka rebab atau dari Ayak-ayak, ketika sirep, bagian ngelik tidak disajikan. Untuk mencari alasannya, tentu diluar koridor permasalahan penelitian ini. Maka, pada bagian ngelik ini, melihat merong kedua dan ketiga yang dominan pathet nem, kemungkinan dominasi pathet nemnya juga berkurang. Mari kita buktikan. 
Merong Keempat/Ngelik

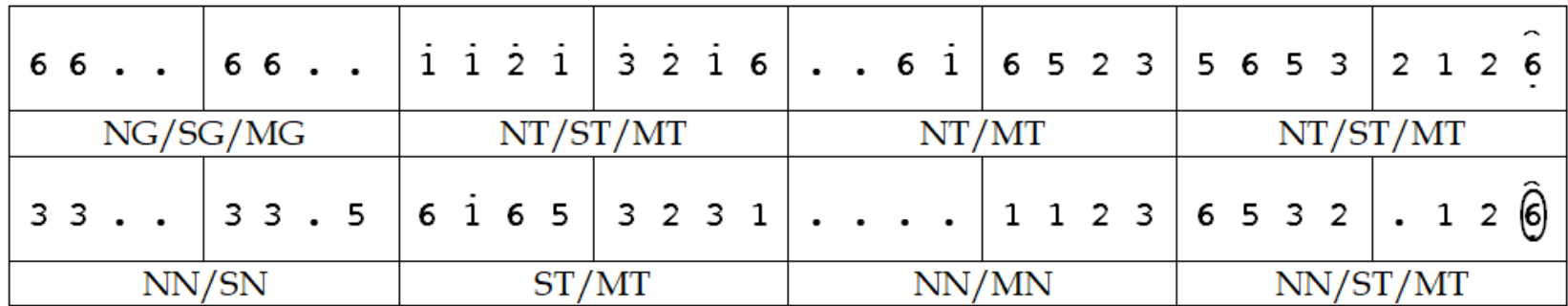

Melihat analisis merong keempat atau ngelik di atas, maka tidak ada yang berfrasa eksklusif nem. F1 dan F2 berpotensi frasa nem, sanga, dan manyura, F3 nem dan manyura, F4 berpotensi nem dan sanga, F7 berpotensi nem dan manyura dan terakhir, F8 berpotensi untuk frasa nem, sanga, dan manyura. Tabel di atas menunjukan bahwa merong keempat D ini tidak dominan pathet nem dan lebih dominan frasa pathet manyura. Kenapa demikian, karena biang pathet menunjukan bahwa dari F1 hingga F8, frasa manyura ini selalu hadir kecuali pada F5. Meski pathet nem jumlah biang pathetnya sama dengan biang pathet manyura, karakter gantungan, yang ada pada F5 memperlemah pathet nem itu sendiri. Hal tersebut mengindikasikan bahwa merong keempat ini bernuansa pathet manyura dominan, diikuti nem, dan terendah pathet sanga.

Merong Kelima/ Ngelik

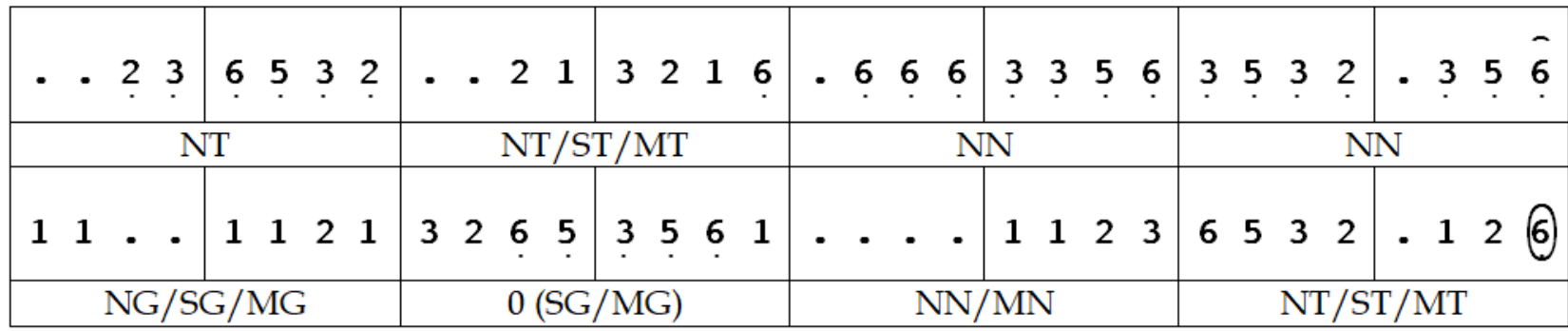

Merong kelima ngelik ini bila analisis maka F1 hingga F3 sama dengan F5 hingga F7 merong ngelik. Sebuah ciri khas pengulangan kalimat lagu ketawang gending; frasa menuju gong memiliki kemiripan dengan frasa kenong gong berikutnya - perlu penelitian lebih mendalam tentunya. Perbedaannya terletak pada F4, yang bila pada F8 merong keempat frasanya menurun, pada F4 merong ngelik kelima E ini naik. Setelah itu, kemudian pada F5 hingga F8 sama dengan F6 hingga F8 merong pertama Gending Krawitan.Tidak ada frasa ekslusif pada F1 hingga F4 dan dominan manyura. Dominasi ini berlanjut pada F5 dan F6 baru kemudian disambut frasa ekslusif pathet nem atau F7 dan ditutup dengan frasa yang berpotensi pathet nem, sanga, dan manyura. Hasil analisanya, pada bagian merong ngelik kelima ini, pathet nem hadir tetapi tidak dominan yakni pada F1, kemudian frasa berganti dominan manyura karena keberadaanya yang mengalahkan frasa sanga dan nem pada F2 hingga F4. F5 frasa manyura menguat hingga F6, kemudian ada frasa eksklusif pada F7 berpengaruh pula pada F8 yang menjadi kuat frasa nemnya. Artinya, merong kelima ini, meski pada awal dominan pathet manyura, mendekati seleh kalimat lagu gong, pathet nem berasa menguat atau dapat dikatakan pathet nem akhirnya menguat. Sajian Kembali ke merong kedua - ketiga lalu merong keenam. 
Merong Keenam

\begin{tabular}{|c|c|c|c|c|c|c|c|c|}
\hline 33 & 33 & . 5 & 6 i 65 & $\begin{array}{llll}3 & 2 & 3 & 1\end{array}$ & - & $\begin{array}{llll}1 & 1 & 2 & 3\end{array}$ & $\begin{array}{llll}6 & 5 & 3 & 2\end{array}$ & - 126 \\
\hline \multicolumn{3}{|c|}{$\mathrm{NN} / \mathrm{SN}$} & \multicolumn{2}{|c|}{$\mathrm{ST} / \mathrm{MT}$} & \multicolumn{2}{|c|}{$\mathrm{NN} / \mathrm{MN}$} & \multicolumn{2}{|c|}{$\mathrm{NN} / \mathrm{MN}$} \\
\hline . 6 & 66 & - & $66 \mathrm{i}$ & $\begin{array}{llll}5 & 3 & 2 & 3\end{array}$ & $\begin{array}{llll}5 & 6 & 5 & 3\end{array}$ & $\begin{array}{llll}2 & 1 & 6 & 5\end{array}$ & $\begin{array}{llll}3 & 5 & 6 & 1\end{array}$ & $\begin{array}{llll}3 & 2 & 1 & 6\end{array}$ \\
\hline \multicolumn{3}{|c|}{ NG/SG/MG } & \multicolumn{2}{|c|}{ NT/MT } & \multicolumn{2}{|c|}{ NT } & \multicolumn{2}{|c|}{ NT/ST/MT } \\
\hline
\end{tabular}

Merong keenam ini merupakan lanjutan dari merong ketiga di mana frasa eksklusif terletak pada kalimat/ frasa seleh gong atau seleh kuat merong ketiga yang berlanjut pada F1 merong keenam F ini. Kemudian pada F2 yang hadir dapat nem, sanga, dan manyura, yang keberadaanya kemudian diluluhkan pada F3 dan F4 sebagai frasa eksklusif pathet nem. F4 merupakan frasa nem, sanga, dan manyura, dilanjutkan F6 yang oleh biang pathet tidak terdeteksi frasanya, apakah naik, turun atau gantung. Merujuk penjelasan Hastanto, nada 1 tengah (barang tengah) jarang sekali eksis sebagai frasa seleh maupun gantungan (Hastanto, 2009 : 149). Hal ini mengapa terjadi, karena bila itu sering dimunculkan, maka akan menghancurkan rasa pathet nem. Bila melihat fenomena tersebut pada Gending Krawitan, ada dua frasa yang tidak dapat dapat dideteksi dari biang pathet, yakni pada F6 merong keenam F dan pada merong kedelapan H pada F3 (nanti akan kita jumpai). Pada kasus F0 tersebut, pada contoh analisisnya pada Ladrang Bedhat laras slendro pathet nem, Hastanto memasukannya pada frasa gantungan sanga dan manyura. Sedangkan atmosfir pathetnya, sesuai dengan pathet yang mengelilinginya. Maka pada bagian F6 di atas bernuansa pathet nem. F7 dan F8nya, berpotensi pathet nem, sanga, dan manyura. Maka merong keenam F ini dapat dipastikan dominan pathet nem.

Merong Ketujuh

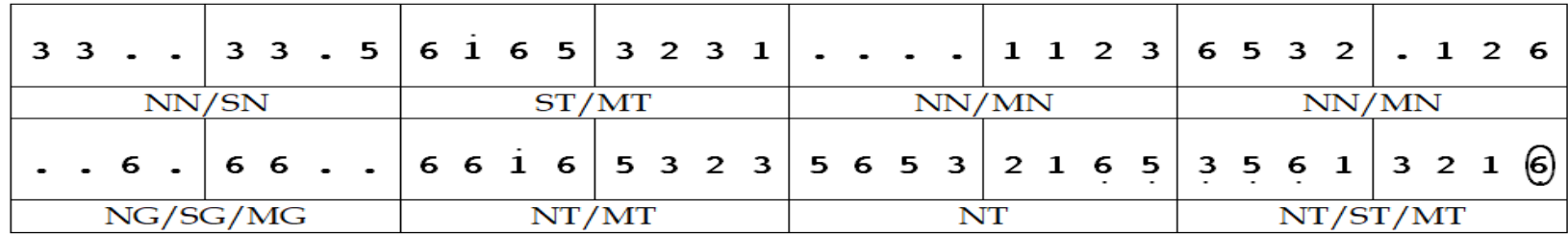

Frasa merong ketujuh ini sama dengan frasa pada merong ngelik kelima. Maka kesimpulannya juga dapat dipastikan tidak akan berbeda. Analisa berlanjut pada bagian merong kedelapan berikut ini.

Merong Kedelapan - Umpak Inggah 


\begin{tabular}{|c|c|c|c|c|c|c|c|}
\hline $\begin{array}{llll}3 & 5 & 6 & 5\end{array}$ & $\begin{array}{llll}2 & 2 & 3 & 2\end{array}$ & $\begin{array}{llll}5 & 6 & 5 & 3\end{array}$ & $\begin{array}{llll}2 & 1 & 2 & 6\end{array}$ & . 36 . & $\begin{array}{llll}3 & 5 & 6 & 1\end{array}$ & $.3 \cdot 2$ & $\cdot 1 \cdot \overline{6}$ \\
\hline \multicolumn{2}{|c|}{$\mathrm{NN} / \mathrm{SN}$} & \multicolumn{2}{|c|}{ NT/ST/MT } & \multicolumn{2}{|c|}{0 (SG/MG) } & \multicolumn{2}{|c|}{ NT/ST/MT } \\
\hline$\cdot 2 \cdot 1$ & $.2 \cdot 6$ & . $2 \cdot 1$ & . $2 \cdot 6$ & $\cdot 2 \cdot 1$ & . $2 \cdot 6$ & $\cdot 3 \cdot 2$ & $\cdot 5 \cdot 6$ \\
\hline
\end{tabular}

Analisa pada merong kedelapan $\mathrm{H}$ ini pada F1 dan F2nya sama dengan merong kedua B. F3 adalah sama kasus F6 merong keenam F. Lalu pada F4 hingga F7, ada frasa yang berpotensi nem, sanga, dan manyura, dan kemudian ditutup dengan frasa eksklusif pathet nem. Setelah bagian merong selesai dianalisis, mari kita lihat hasil dominasi pathetnya per merong. Hasil analisis per merong disajikan dalam bentuk tabel.

Tabel 3 . Hasil Analisis Bagian Merong (Sumber: Sigit Setiawan, 2021)

\begin{tabular}{|c|c|c|c|}
\hline \multirow[b]{2}{*}{ Merong } & \multicolumn{3}{|c|}{ Nilai Dominasi Patlıet } \\
\hline & $\begin{array}{l}\text { Tidak Dominan } \\
\text { Pathet Nem/ } \\
\text { dominan pathet } \\
\text { selain nem }\end{array}$ & $\begin{array}{c}\text { Pathet nem kuat } \\
\text { pada sebagian } \\
\text { frasa gong }\end{array}$ & $\begin{array}{c}\text { Dominan Pathet } \\
\text { Nem }\end{array}$ \\
\hline Merong Pertama A & & $\sqrt{ }$ & \\
\hline Merong Kedua B & & & $\sqrt{ }$ \\
\hline Merong Ketiga C & & & $\sqrt{ }$ \\
\hline Merong Keempat Ngelik D & $\sqrt{ }$ & & \\
\hline Merong Kelima Ngelik E & & $\sqrt{ }$ & \\
\hline Merong Keenam F & & & $\sqrt{ }$ \\
\hline Merong Ketujuh G & & $\sqrt{ }$ & \\
\hline $\begin{array}{l}\text { Merong Kedelapan }- \text { Umpak } \\
\text { Inggah } \mathrm{H}\end{array}$ & & $\sqrt{ }$ & \\
\hline
\end{tabular}

Hasil analisis yang telah dilakukan pada bagian merong Gending Krawitan, terdapat tiga kesimpulan. Pertama, terdapat satu sajian merong dengan frasa tidak dominan pathet nem yakni pada merong ngelik keempat. Bagian yang pada kasus Gending Krawitan bisa saja tidak disajikan. Kedua, terdapat frasa-frasa yang pada awal kalimat lagu tidak berpathet nem saja, tetapi pada akhir kalimat seleh gong berpathet dominan nem, yakni pada merong pertama, kelima ngelik yang bisa saja tidak disajikan, ketujuh dan kedelapan. Ketiga, terdapat merong dengan dominan pathet nem yaitu pada merong kedua, ketiga, dan keenam. Atas data dan simpulan di atas, jelas sudah bahwa Gending Krawitan pada bagian merongnya adalah pathet nem.

Setelah melihat hasil analisis pathet pada bagian merong, selanjutnya, mari kita lihat analisis pathet pada bagian inggah atau bagian ladrang. Berikut analisanya.

Ladrang Pertama 


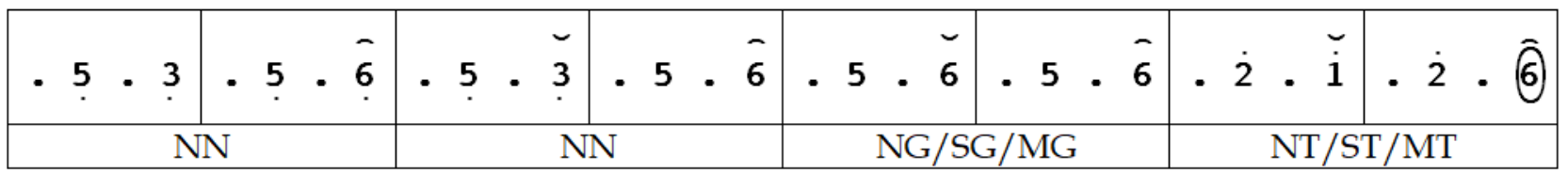

Frasa pada gong pertama ladrang ini adalah terdapat frasa eksklusif pathet nem yakni pada F1 dan F2. Selanjutnya, pada F3 dan F4, adalah frasa yang bisa jadi nem, sanga, dan manyura. Keberadaan frasa eksklusif tersebut memberi nuansa pathet nem pada setengah gongnya, tetapi berubah menjadi frasa pathet lain kemudian. Dengan demikian dapat disimpulkan bahwa gong ladrang pertama ini bernuansa pathet nem pada sebagian frasa setiap gong.

Ladrang Kedua

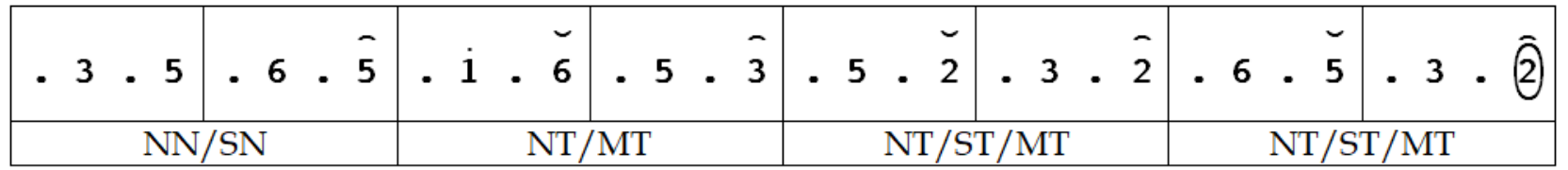

Gong kedua ladrang ini, dari analisis pathetnya tidak ada yang dominan frasa nemnya. Masing-masing frasa berpotensi pathet lebih dari satu, yaitu F1 nem dan sanga, F2 nem dan manyura, F4 dan F5, berpotensi nem, sanga, dan manyura. Maka gong kedua ini, pathet nem disimpulkan "bukan tidak ada" tetapi "ada tapi tidak dominan".

Ladrang Ketiga

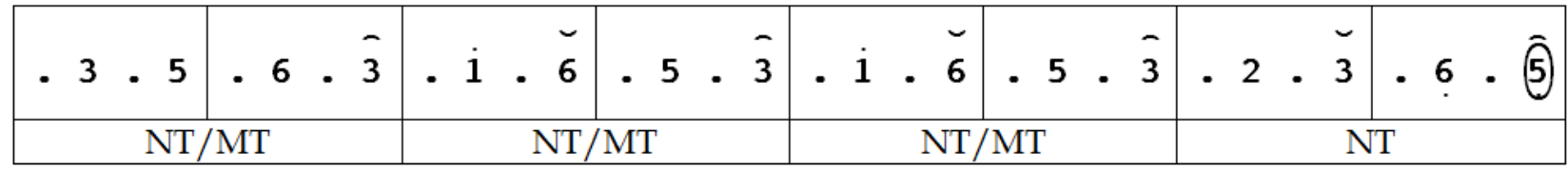

Pada gong ketiga, hasil analisis pathetnya menunjukan; F1, F2 dan F3 bernuansa nem dan manyura, sedangkan frasa eksklusif pathet nem berkibar pada F8. Hal ini menunjukkan, meski frasafrasa tidak dominan pada awal kalimat lagu gending, ketika kalimat lagu pada seleh berat menunjukan frasa ekslusif maka dapat dipastikan bahwa gong ketiga ladrang ini adalah wujud dominasi pathet nem.

Ladrangan Keempat

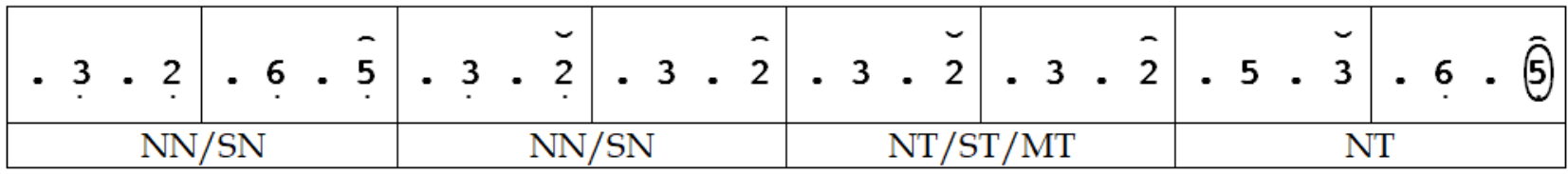

Gong terakhir ladrang Krawitan ini menunjukan konsistensi pathet nem hadir pada F1 dan F2 karena dipengaruhi oleh frasa eksklusif pada F8 gong sebelumnya. Lalu F3 bernuansa frasa nem, sanga, dan manyura, untuk kemudian ditutup dengan frasa eksklusif slendro nem pada F8. Hasil analisis menunjukan bahwa gong terakhir ini bernuansa dominan pathet nem. Hasil analisis pada bagian ladrang ini dapat diamati pada tabel berikut.

Tabel 4 . Hasil Analisis Bagian Ladrang

(Sumber: Sigit Setiawan, 2021) 


\begin{tabular}{|l|c|c|c|}
\hline \multirow{2}{*}{\multicolumn{1}{|c|}{ Merong }} & \multicolumn{3}{|c|}{ Nilai Dominasi Pathet } \\
\cline { 2 - 4 } & $\begin{array}{c}\text { Tidak Dominan } \\
\text { Pathet Nem/ } \\
\text { dominan pathet } \\
\text { selain nem }\end{array}$ & $\begin{array}{c}\text { Pathet nem kuat } \\
\text { pada sebagian } \\
\text { frasa gong }\end{array}$ & $\begin{array}{c}\text { Dominan Pathet } \\
\text { Nem }\end{array}$ \\
\hline Ladrang Pertama A & & & $\sqrt{ }$ \\
\hline Ladrang Kedua B & $\sqrt{ }$ & $\sqrt{ }$ \\
\hline Ladrang Ketiga C & & & $\sqrt{ }$ \\
\hline Ladrang Ngelik D & & & \\
\hline
\end{tabular}

Kesimpulan akhir dari analisis bagian ladrang di atas menyatakan bahwa inggah Gending Krawitan ini berpathet nem. Bila hasil analisis Gending Krawitan bagian merong dan ladrang digabungkan, kesimpulan yang diambil adalah; Gending Krawitan ini memang benar-benar berpathet nem.

\section{Kesimpulan}

Sebelum menyimpulkan penelitian ini, ijinkan penulis untuk memetakan beberapa kekurangan menurut versi penulis. Tentu pula, bahwa penelitian ini juga mengharapkan sepenuhnya penilaian dari peneliti berikutnya. Pertama, kekurangan dari penelitian ini masih banyak istilah teknis yang kemungkinan besar hanya dapat dipahami oleh para praktisi, peneliti, pembaca yang memang telah mengenal karawitan. Bagi para pembaca umum, tentu membaca tulisan ini perlu tenaga yang lebih ekstra. Kedua, kedalaman analisis yang masih belum bebles, sehingga kemungkinan subyektifitas masih hadir dalam penelitian ini. Meski demikian, penulis sudah berusaha untuk bekerja secara obyektif. Ada banyak konsep-konsep garap yang belum sepenuhnya terjelaskan, seperti salah satunya konsep sirep. Sehingga peluang untuk mengeksplanasi itu semua sangat sangat terbuka. Ketiga, Gending Krawitan, pada tatanan garap berpeluang untuk dikaji lebih lanjut perihal variasi jalan sajiannya, misalkan untuk keperluan pakeliran gaya tertentu misalkan gaya Klatenan. Pembahasan Gending Krawitan sebagai gending beksan seperti beksan topeng di Klaten, dan juga modifikasi Blacius Subono yang menggunakannya sebagai salah satu gending drama tari Matah Ati 2013-an juga jelas belum dapat dilakukan pada penelitian ini. Belum lagi Gending Krawitan dalam konteks klenengan. Kiranya penting mencatat itu semua, supaya minimal bagi penulis, Gending Krawitan dapat digunakan sebagai obyek penelitian berikutnya.

Berbicara kesimpulan, Gending Krawitan ini, yang berbentuk ketawang gending kethuk 4 kerep minggah ladrang, merupakan pemekaran dari bentuk ketawang. Sedangkan dari segi jalan sajiannya, terkait dengan garap pakeliran, setidaknya ada dua versi, yaitu versi buka rebab dan versi dari ayak-ayak. Dinamika irama yang dilibatkan, seperti yang tertera pada pembahasan, Gending ini, melewati, irama lancar, tanggung, dadi, dan wilet. Terakhir, berdasarkan analisis pathet, berhasil menunjukan bahwa Gending Krawitan, memang berpathet nem. 


\section{Daftar Pustaka}

Ahimsa-Putra, Heddy Shri. 2000. “Ketika Orang Jawa Nyeni.” In . Yogyakarta: Galang Press.

Aji, Nanang bayu. 2019. “Sistem Garap Pada Balungan Cengkok Mati Dalam Karawitan Tradisi Gaya Surakarta." ISI Surakarta.

Asmoro, Purbo. 2013. Raja Suya : Teks Pagelaran Ringgit Purwa Wacucal Tigang Gagrak. Jakarta: Lontar Fondation.

Emerson, Kathryn Anne Emerson. 2017. Pembaharuan Wayang Untuk Penonton Terkini : Gaya Pakeliran Garap Semalam Sajian Dramatik Ki Purbo Asmoro 1989 - 2017. Surakarta: ISI Press.

Hanifah, Listi, Rahayu, Irma Apriliyani, Rinata, Septian. 2019. “Bentuk Istilah-Istilah Upacara Panggih Pernikahan Adat Jawa : Kajian Etnolinguistik." LITE 15 (2).

Hastanto, Sri. 2009. Konsep Pathet Dalam Karawitan Jawa. Surakarta: ISI Press.

Junaidi, Sugiarto, Asal. 2018. “Hubungan Wayang Dan Gending Dalam Pakeliran Wayang Kulit Purwa Gaya Surakarta." Wayang Nusantara: Journal of Puppetry 2 (1): 19-27.

Martopangrawit. 1975. Pengetahuan Karawitan I Dan II. Surakarta: ASKI Surakarta.

Mloyowidodo. 1977. Gending-Gending Jawa Gaya Surakarta Jilid I, II, III. Surakarta: ASKI Surakarta.

Nayawirangka. 1960. Serat Pedalangan Lampahan Irawan Rabi, Jilid I. Surakarta: Djawatan Kebudajaan Kementrian P.P. dan K.

Nyoman Kutha, Ratna. 2010. Metodologi Penelitian Kajian Budaya Dan Ilmu Sosial Humaniora Pada Umumnya. Yogyakarta: Pustaka Pelajar.

Reno, Wikandaru, Lasiyo, Sayuti, Suminto A. 2019. “Ontologi Pathet : Kajian Kritis Terhadap Pathet Sebagai Representasi Norma Ontologis Transedental Dalam Pergelaran Wayang." Filsafat 29 (2).

Rustopo. 2014. Perkembangan Gending-Gending Gaya Surakarta 1950-2000-An. Surakarta: ISI Press.

Setiawan, Sigit. 2015. “Konsep Kendangan Pematut Karawitan Jawa Gaya Surakarta.” Surakarta: Tesis Program Studi Pengkajian Seni Minat Musik ISI Surakarta.

- - - 2020. “Subakastawa Dalam Perspektif Ragam Garap Penyajiannya.” Keteg: Jurnal Pengetahuan, Pemikiran Dan Kajian Tentang Bunyi 20 (2): 183-92.

Soetarno, Soetarno. 2011. "Gaya Pedalangan Wayang Kulit Purwa Jawa Serta Perubahannya." Mudra 26 (1): 1-16.

Sudarko. 2010. “Perbandingan Struktur Adegan Pakeliran Wayang Kulit Purwa Gaya Surakarta Dan Yogyakarta." Gelar: Jurnal Seni Budaya 8 (1).

Sukamso. 2015. "Konvensi-Konvensi Dalam Pementasan Karawitan Klenengan Tradisi Gaya Surakarta." Keteg: Jurnal Pengetahuan, Pemikiran Dan Kajian Tentang" Bunyi" 15 (1): 49-59.

Sumarsam. 2003. Gamelan: Interaksi Budaya Dan Perkembangan Musikal Di Jawa. Pustaka Pelajar.

- - - 2018. “Memaknai Wayang Dan Gamelan.” In . Yogyakarta: Gading.

Supanggah, Rahayu. 2006. Garap: Salah Satu Konsep Pendekatan/Kajian Musik Nusantara," Dalam Menimbang Pendekatan: Pengkajian Dan Penciptaan Musik Nusantara. Edited by Waridi. Surakarta: STSI Press. 


\section{KÊTTÉC}

Jurnal Pengetahuan, Pemikiran dan Kajian Tentang Bunyi

- - - . 2007. "Bothekan Karawitan II." Jakarta: Masyarakat Sèni Pertunjukan Indonesia.

Suparto. 2021. “Tembang Macapat Sebagai Sumber Ide Gending-Gending Karya Ki Nartosabdo.” Selonding 1 (1).

Waridi. 2001. Martopangrawit Empu Karawitan Gaya Surakarta. Yogyakarta: Mahavhira.

\section{Diskografi}

KWK 100. 1992. Kresna Duta. Pimp. Anom Suroto. Klaten, Kusuma Record.

Link : https://www.youtube.com/watch?v=BX5hnuK2EkM\&t=1345s

WD 357. 1990(?). Parikesit Grogol. Pimp. Narto Sabdo. Surakarta, Dahlia Record.

Link : https:/ / www.youtube.com/watch?v=xD729UbP9x0\&t=274s

Materi Ajar Jurusan Pedalangan. Jejer Dwarawati. Surakarta, ISI Surakarta

Link : https://www.youtube.com/watch?v=96jxOGkuEC8\&t=359s 